The age of the martian meteorite

Northwest Africa 1195 and the differentiation history of the shergottites

S. Symes, L. Borg, C. Shearer, A. Irving

April 5, 2007

Geochimica et Cosmochimica Acta 
This document was prepared as an account of work sponsored by an agency of the United States Government. Neither the United States Government nor the University of California nor any of their employees, makes any warranty, express or implied, or assumes any legal liability or responsibility for the accuracy, completeness, or usefulness of any information, apparatus, product, or process disclosed, or represents that its use would not infringe privately owned rights. Reference herein to any specific commercial product, process, or service by trade name, trademark, manufacturer, or otherwise, does not necessarily constitute or imply its endorsement, recommendation, or favoring by the United States Government or the University of California. The views and opinions of authors expressed herein do not necessarily state or reflect those of the United States Government or the University of California, and shall not be used for advertising or product endorsement purposes. 


\section{The age of the martian meteorite Northwest Africa 1195 and the differentiation history of the shergottites}

Steven J. K. Symes ${ }^{1 *}$, Lars E. Borg ${ }^{2 \dagger}$, Charles K. Shearer ${ }^{2}$, and Anthony J. Irving ${ }^{3}$

${ }^{1}$ Department of Chemistry, University of Tennessee-Chattanooga, Chattanooga, TN 37403, USA

${ }^{2}$ Institute of Meteoritics, University of New Mexico, Albuquerque, NM 87131, USA

${ }^{3}$ Department of Earth and Space Sciences, University of Washington, Seattle, WA 98195 USA

${ }^{\dagger}$ Now at Lawrence Livermore National Laboratory, Chemistry Sciences Division, Livermore, CA 94550 USA

*Author to whom correspondence should be addressed (Steven-Symes@utc.edu).

In Preparation for Geochimica et Cosmochimica Acta 
Abstract. Samarium-neodymium isotopic analyses of unleached and acid-leached mineral fractions from the recently identified olivine-bearing shergottite Northwest Africa 1195 yield a crystallization age of $348 \pm 19 \mathrm{Ma}$ and an $\varepsilon_{N d}^{143}$ value of $+40.1 \pm 1.3$. Maskelynite fractions do not lie on the Sm-Nd isochron and appear to contain a martian surface component with low ${ }^{147} \mathrm{Sm} /{ }^{144} \mathrm{Nd}$ and ${ }^{143} \mathrm{Nd} /{ }^{144} \mathrm{Nd}$ ratios that was added during shock. The Rb-Sr system is disturbed and does not yield an isochron. Terrestrial Sr appears to have affected all of the mineral fractions, although a maximum initial ${ }^{87} \mathrm{Sr} /{ }^{86} \mathrm{Sr}$ ratio of $0.701614 \pm 16$ is estimated by passing a $348 \mathrm{Ma}$ reference isochron through the maskelynite fraction that is least affected by contamination. The high initial $\varepsilon_{N d}^{143}$ value and the low initial ${ }^{87} \mathrm{Sr} /{ }^{86} \mathrm{Sr}$ ratio, combined with the geologically young crystallization age, indicate that Northwest Africa 1195 is derived from a source region characterized by a long-term incompatible element depletion.

The age and initial Sr and Nd isotopic compositions of Northwest Africa 1195 are very similar to those of Queen Alexandra Range 94201, indicating these samples were derived from source regions with nearly identical $\mathrm{Sr}-\mathrm{Nd}$ isotopic systematics. These similarities suggest that these two meteorites share a close petrogenetic relationship and might have been erupted from a common volcano. The meteorites Yamato 980459, Dar al Gani 476, Sayh al Uhaymir 005/008, and Dhofar 019 also have relatively old ages between 474-575 Ma and trace element and/or isotopic systematics that are indicative of derivation from incompatible-element-depleted sources. This suggests that the oldest group of meteorites is more closely related to one another than they are to the younger meteorites that are derived from less incompatible-element-depleted sources. Closed-system fractional crystallization of this suite of meteorites is modeled with the MELTS algorithm using the bulk composition of Yamato 980459 as a parent. These models reproduce many of the major element and mineralogical variations observed in the suite. In 
addition, the rare-earth element systematics of these meteorites are reproduced by fractional crystallization using the proportions of phases and extents of crystallization that are calculated by MELTS. The combined effects of source composition and fractional crystallization are therefore likely to account for the major element, trace element, and isotopic diversity of all shergottites. Thus, assimilation of a martian crustal component is not required to explain the geochemical diversity of the shergottites.

\section{INTRODUCTION}

Approximately 38 unpaired meteorites have been identified as samples of the planet Mars. All of them have an igneous origin and thus formed by crystallization of magma on or near the surface of Mars. The martian meteorites comprise four major rock types including an orthopyroxenite, clinopyroxenites, dunites, and shergottites (e.g. McSween, 1994). The shergottites have been further divided into four subclasses; olivine-phyric, olivineorthopyroxene-phyric, lherzolitic, and basaltic shergottites (i.e., those that contain plagioclase and Ca-Fe-rich pyroxenes). The shergottites demonstrate a range of major and trace element compositions, initial $\mathrm{Sr}, \mathrm{Nd}, \mathrm{Hf}$, and $\mathrm{Pb}$ isotopic compositions, and crystallization ages. The compositional differences have been interpreted to reflect either varying degrees of assimilation of martian crust (e.g., Jones, 1989; Borg et al., 1997; Herd et al., 2002; McSween et al., 2003), or that they have been inherited from their mantle source regions (e.g., Borg et al., 2003; Borg and Draper, 2003).

Assimilation and fractional crystallization (AFC) occurs when a mafic magma undergoes differentiation and interacts with a light-rare-earth-element (LREE)-enriched crustal reservoir. As the heat needed to assimilate the crustal country rock must come from the latent heat of 
crystallization of a cooling magma, it is expected that the most LREE enriched samples will be more extensively differentiated samples. Thus, assimilation fractional crystallization should produce a correlation between an index of differentiation, such as $\mathrm{Mg} \#$ of the parental melt, and an index of incompatible-element-enrichment, such as the chondrite normalized $\mathrm{La} / \mathrm{Yb}$, $(\mathrm{La} / \mathrm{Yb})_{\mathrm{N}}$, ratio (Borg and Draper, 2003). Because $\mathrm{La}$ and $\mathrm{Yb}$ are similarly incompatible in assemblages containing olivine and pyroxene, the $\mathrm{La} / \mathrm{Yb}$ ratio will not be strongly altered by fractional crystallization. This is demonstrated by the observation that estimates of shergottite parental liquids for depleted, enriched, and intermediate samples have REE patterns that are parallel to their respective whole-rock patterns (McSween et al., 1996; Wadhwa et al., 1994) so that $\mathrm{La} / \mathrm{Yb}$ ratios of the whole-rocks can be used as a proxy for the parental liquid. Figure 1 shows that the expected correlation does not exist, suggesting that variations in the geochemical characteristics observed in the shergottite suite do not result from simple AFC of a common parent magma interacting with a generally similar assimilant characterized by high a $(\mathrm{La} / \mathrm{Yb})_{\mathrm{N}}$ ratio. Instead, these geochemical and isotopic variations could be the result of either: (1) a complex AFC scenario involving multiple compositionally distinct parent magmas interacting with multiple compositionally distinct assimilants, or (2) closed-system fractional crystallization of parental melts derived from different mantle source regions.

The goal of this study is to constrain the physical mechanisms by which the shergottites obtain their compositional characteristics. This is accomplished by determining the crystallization age and $\mathrm{Sr}$ and $\mathrm{Nd}$ isotopic systematics of a mafic martian meteorite Northwest Africa 1195 (NWA1195), thus defining its petrogenetic linkage to other martian meteorites. Then, the compositional variations observed in a subset of martian meteorites are modeled using fractional crystallization algorithms. The success or failure of these models potentially dictates 
whether fractional crystallization of martian magmas is accompanied by assimilation of martian crust. Ultimately this underscores whether the isotopic variation observed in the broader martian meteorite suite reflects compositional variability in their source regions or the assimilation of evolved crustal material in a martian magma chamber. Our results indicate that NWA1195 has a crystallization age of $348 \mathrm{Ma}$ and initial $\mathrm{Sr}$ and $\mathrm{Nd}$ isotopic compositions that are very similar to Queen Alexandra Range 94201 (QUE), Dhofar 019, Dar al Gani 476 (DaG), and Yamato 980459 (Y98) suggesting that these meteorites are derived from nearly identical source regions. Major and trace element models demonstrate that the compositional variations within this subset of martian meteorites are consistent with fractional crystallization, suggesting that these martian meteorites do not evolve by simple assimilation fractional crystallization.

\section{PETROLOGY OF NORTHWEST AFRICA 1195}

This specimen was found near the village of Safsaf close to the Algeria-Morocco border (Irving et al., 2002), and has a narrow weathering rind that was avoided in sample preparation for this study. Petrographically it resembles other olivine-pyroxene-bearing shergottites such as DaG 476, NWA 2046, and NWA 2626 (Irving et al., 2004). Northwest Africa 1195 is an olivine-orthopyroxene-phyric shergottite containing large olivine phenocrysts (up to $4 \mathrm{~mm}$ long) and prismatic low-Ca pyroxene phenocrysts in a finer grained groundmass of pigeonite, olivine, maskelynite, chromite, ilmenite, pyrrhotite and merrillite. The maskelynite has a limited range of compositions from $\mathrm{An}_{63}$ to $\mathrm{An}_{59}$. Compositions of both olivine phenocrysts (zoned from $\mathrm{Fo}_{81}$ cores to $\mathrm{Fo}_{60}$ rims) and pyroxene phenocrysts (core compositions $\mathrm{En}_{83} \mathrm{Wo}_{2}$ ) imply that the parent magma was relatively mafic $(\mathrm{Mg} \#=59$; Irving et al., 2004). Pyroxenes have a light brown color and appear relatively fresh; olivine is darker brown, but this color is not caused by obvious 
chemical alteration, and instead may be a result of shock darkening. Minor calcite present along grain boundaries and traces of interstitial barite are the only apparent products of terrestrial weathering of the otherwise fresh interior of this meteorite, which has been determined to have a terrestrial age of $\sim 37 \mathrm{Ka}$ (A. J. T. Jull, unpubl. data).

\section{ANALYTICAL TECHNIQUES}

An $850 \mathrm{mg}$ split of NWA1195 was crushed in a sapphire mortar and pestle. Prior to sieving, a whole-rock fraction (Wr-1) was set aside. Then large olivines were handpicked from the remaining material. The remainder was sieved at $74-150 \mu \mathrm{m}, 44-74 \mu \mathrm{m}$, and $<44 \mu \mathrm{m}$. A second whole-rock fraction (Wr-2) was obtained from the $<44 \mu \mathrm{m}$ fines. Minerals were handpicked from the two largest sieve fractions after passing through a Frantz isodynamic separator. The mineral separation procedure resulted in a total of 8 fractions including 2 fractions each of whole-rock, maskelynite, and Mg-rich pyroxene and 1 fraction each of olivine and Fe-rich pyroxene. Because the sample is from a hot desert, and since backscatter electron images revealed the presence of terrestrial calcite veins, all fractions (except Wr-1 and Olivine) were leached for $10 \mathrm{~min}$ in an ultrasonic bath in warm acetic acid and $1 \mathrm{~N} \mathrm{HCl}$ prior to digestion. The unleached fractions and the residues from the leaching procedure were analyzed for $\mathrm{Rb}-\mathrm{Sr}$ and Sm-Nd isotopic compositions. Element separations utilized hydrochloric and methyllactic acids and various cation exchange resins (see Borg et al., 2005 for detailed description of analytical techniques). All samples were analyzed statically using a multi-collector Micromass Sector 54 thermal ionization mass spectrometer with $\mathrm{Nd}$ and Sm run as oxides, following the procedures of Borg et al. (2005). Procedural blanks were as follows: 5pg Sm, 7pg Nd, 6pg Rb, and 11pg Sr. 


\section{RESULTS}

\subsection{Sm-Nd Isotopic Systematics}

The ${ }^{147} \mathrm{Sm} /{ }^{144} \mathrm{Nd}$ and ${ }^{143} \mathrm{Nd} /{ }^{144} \mathrm{Nd}$ isotopic data are presented in Table 1 and in Figure 2. Two whole rock fractions and three mineral separates (two pyroxenes and an olivine fraction) define a crystallization age of $348 \pm 19 \mathrm{Ma}$ for $\lambda\left({ }^{147} \mathrm{Sm}\right)=0.00654 \mathrm{Ga}^{-1}$ and yield an initial $\varepsilon_{N d}^{143}$ value of $+40.1 \pm 1.3$. The isochron is defined by unleached fractions (Wr-1 and Olivine) as well as residue fractions. Although the three residue fractions could define the isochron, and would yield an age of $358 \mathrm{Ma}$, we have included the unleached fractions in the regression because they expand the range of measured ${ }^{147} \mathrm{Sm} /{ }^{144} \mathrm{Nd}$ ratios. It is unlikely that the unleached fractions contain a significant proportion of a terrestrial contaminant because that contaminant would have to fortuitously lie along an extension of the three residue fractions. Furthermore, control of the $\mathrm{Sm}-\mathrm{Nd}$ isotopic systematics by contamination is implausible because it requires the contaminant to have a fairly radiogenic Nd isotopic composition, whereas Saharan surface materials are known to have very unradiogenic $\mathrm{Nd}$ near ${ }^{143} \mathrm{Nd} /{ }^{144} \mathrm{Nd}=0.512$ (Schaaf and Müller-Sohnius, 2002). Thus, we interpret the Wr-1 and Olivine fractions to be in isotopic equilibrium with the three residue fractions.

Like other olivine-bearing shergottites, NWA1195 contains olivine "megacrysts". There is some debate as to the origin of these large olivine crystals, in particular whether they are xenocrysts or true phenocrysts. Although detailed petrographic studies of NWA1195 are needed to fully address this issue, we observe that the olivine mineral fraction is in isotopic equilibrium with pyroxene and the bulk rock fractions. This is consistent with a phenocrystic origin for olivine in NWA1195. 
The age determined here for NWA1195 is concordant with the Sm-Nd ages determined

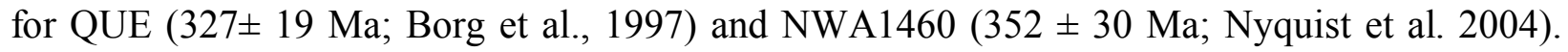
Furthermore, the age and isotopic systematics of NWA1195 are almost identical to those of QUE suggesting that these two meteorites are very closely related and might even be derived from the same volcanic source. Nevertheless, NWA1195 has slightly lower initial Nd and slightly higher Sr isotopic compositions (see below) indicating it is derived from a source region that is somewhat less depleted in incompatible elements.

The $\sim 340$ Ma samples define the third most common martian meteorite age group behind the $\sim 175 \mathrm{Ma}$ age shergottites and the $1.3 \mathrm{Ga}$ age nakhlites (Borg and Drake, 2005). It thus appears that large groups composed of mineralogically, geochemically, and isotopically distinct meteorites are being delineated as more age dating is completed and as more and more meteorites are found. Note that meteorites with ages other than those defined by the three groups are relatively rare. This suggests that the age groups may be used to distinguish sampling events on the martian surface (Nyquist et al., 1998; 2001; Borg and Drake, 2005). The basaltic and lherzolitic meteorites from each age group could therefore represent a closely related suite of samples that are derived from discrete vents or edifices on Mars. If so, then the large compositional diversity observed within each group suggests that individual vents yield an enormously varied group of lavas over relatively short periods of time.

Acid-washed residues from two maskelynite fractions lie significantly below the isochron. This could, in principle, be related to contributions from the laboratory blank or due to analytical uncertainties resulting from very low abundances of $\mathrm{Nd}$ in these fractions. However, although the Mask $1(\mathrm{R})$ fraction contains $400 \mathrm{pg}$ of Nd and Mask $2(\mathrm{R})$ contains $740 \mathrm{pg}$ of $\mathrm{Nd}$, laboratory blanks of $\sim 7 \mathrm{pg}$ will not significantly disturb the $\mathrm{Nd}$ isotopic compositions of these 
fractions. Likewise the observation that the Mg-Px 2 (R) fraction is almost within error of the isochron yet contains only $640 \mathrm{pg}$ of $\mathrm{Nd}$ suggests that errors associated with analysis of small fractions are not responsible for the deviations of the maskelynite fractions from the $\mathrm{Sm}-\mathrm{Nd}$ isochron.

Terrestrial weathering is also an unlikely explanation for shifting the maskelynite fractions off the isochron because, (1) the $\mathrm{Sm}-\mathrm{Nd}$ isotopic system is resistant to weathering (Borg et al., 2003) and (2) weathering processes are expected to be different in samples from the hot Saharan desert (NWA1195) compared with samples from the cold Antarctic desert (QUE), yet the maskelynite fractions from both meteorites are shifted similarly (Borg et al., 1997). Another possibility is that the Sm-Nd isotopic systematics of the maskelynite could be disturbed by shock processes. In order to shift these fractions below the isochron, the maskelynite must contain a component characterized by low ${ }^{147} \mathrm{Sm} /{ }^{144} \mathrm{Nd}$ and ${ }^{143} \mathrm{Nd} /{ }^{144} \mathrm{Nd}$ ratios. Such a component must therefore be derived from a LREE-enriched source and is potentially characteristic of martian surface materials. Despite fairly aggressive leaching, the contaminant is still present in the analyzed residues suggesting it is incorporated into the maskelynite as opposed to being adsorbed along grain surfaces. Borg et al. (1997) suggested that such a component was added to the maskelynite in QUE when it was converted from plagioclase during shock. This was based on the observation that plagioclase contains low abundances of REE and undergoes a structural change during shock which allows incorporation of extraneous components into the resulting glass (McKay et al., 1998). A similar scenario is envisioned for NWA1195. Finally, it is important to note that a similar component has been observed in highly shocked olivine fractions from the lherzolitic shergottites ALH77005 and LEW88516 (Borg et al., 2002; Edmunson et al., 2005). 


\subsection{Rb-Sr Isotopic Systematics}

The ${ }^{87} \mathrm{Rb} /{ }^{86} \mathrm{Sr}$ and ${ }^{87} \mathrm{Sr} /{ }^{86} \mathrm{Sr}$ isotopic data are presented in Table 2 and in Figure 3 , but yield no age information. Regression of the data for five of the mineral separates gives a slope corresponding to an age of $6.0 \mathrm{Ga}$ for $\lambda\left({ }^{87} \mathrm{Rb}\right)=0.01402 \mathrm{Ga}^{-1}$. This indicates that the $\mathrm{Rb}-\mathrm{Sr}$ system is disturbed, most likely as a result of terrestrial weathering in the hot desert. A similar disturbance of the Rb-Sr system was found for other hot desert finds such as NWA 856 (Brandon et al., 2004) and DaG 476 (Borg et al., 2003). Saharan surface materials have ${ }^{87} \mathrm{Sr} /{ }^{86} \mathrm{Sr}$ values of $\sim 0.709$ and $\sim 0.713$ (Schaaf and Müller-Sohnius, 2002), respectively, indicating that terrestrial $\mathrm{Sr}$ could shift all of the fractions to higher values. The Mask 2 (R) fraction has the lowest ${ }^{87} \mathrm{Sr} /{ }^{86} \mathrm{Sr}$ ratio of any fraction and thus appears to be the least affected by contamination. An initial ${ }^{87} \mathrm{Sr} /{ }^{86} \mathrm{Sr}$ ratio of $0.701614 \pm 16$ is obtained for NWA1195 by regressing a 348 Ma reference isochron through this fraction. This is likely an upper limit as terrestrial $\mathrm{Sr}$ is expected to have increased this ratio. Nevertheless, the initial $\mathrm{Sr}$ and $\mathrm{Nd}$ isotopic compositions of NWA1195 are very similar to those determined from the suite of LREE-depleted shergottites (Fig. 4).

\section{RELATIONSHIP BETWEEN THE OLDEST SHERGOTTITES}

The basaltic shergottites Y98, DaG, Sayh al Uhaymir 005 (SaU), Dhofar 019, and QUE have many similar geochemical features including parallel REE patterns and initial Sr-Nd isotopic systematics. Their strongly LREE-depleted REE patterns and similar, but not identical, low initial $\mathrm{Sr}$ and high initial $\mathrm{Nd}$ isotopic ratios indicate that this suite of samples is derived from several very similar source regions that are characterized by depletions in incompatible elements (Fig. 4). These meteorites are herein referred to as the "depleted" shergottite suite. Although a 
full REE pattern is not available for NWA1195, the whole-rock values of Sm and Nd derived from the isotope-dilution measurements of this study are plotted in Figure 4. As can be seen, the slope of the pattern at $\mathrm{Sm}$ and $\mathrm{Nd}$ is parallel to the whole-rock patterns of other depleted samples and this, combined with the old age, high initial $\mathrm{Nd}$ and low initial $\mathrm{Sr}$ isotopic compositions establishes that NWA1195 belongs to the group of depleted shergottites. The fact that the ages of these meteorites span a range (327 to 575 Ma; Borg et al., 1997; 2001; 2003; Shih et al., 2005; 2007; this study), indicates that they are not directly related to one another. Nevertheless, only the oldest shergottites appear to be derived from depleted source regions, suggesting that this suite of samples is more closely related to one another than they are to basaltic meteorites with younger ages or meteorites with dramatically different $\mathrm{Sr}$ and $\mathrm{Nd}$ isotopic systematics.

The other shergottites appear to define additional rock suites characterized by distinct REE patterns and Sr-Nd isotopic systematics (Fig. 4). A suite of meteorites with essentially flat $\mathrm{REE}$ patterns and/or radiogenic initial $\mathrm{Sr}$ and unradiogenic initial $\mathrm{Nd}$ isotopic compositions include NWA1068/1110, NWA856, Los Angeles, Zagami, and Shergotty. These samples are inferred to be derived from relatively incompatible-element-enriched source regions and are herein referred to as the "enriched" shergottite suite. A group consisting of EET79001 lithologies A and B, NWA480/1460, and the lherzolitic shergottites ALH77005 and LEW88516, have moderately LREE-depleted REE patterns and $\mathrm{Sr}-\mathrm{Nd}$ isotopic systematics that are intermediate between the other two suites of meteorites. These are referred to as the “intermediate" shergottite suite. The depleted suite of samples (i.e., Y98, NWA1195, DaG, Dhofar 019, and QUE) are derived from the most incompatible-element-depleted sources and are the focus of the following discussion. 
Despite similar REE patterns and Sr-Nd isotopic systematics, the depleted shergottites (Fig. 4) demonstrate a range of mineral modes and compositions, as well as major element abundances, indicating that they are derived from parental magmas of different composition. One end of this mineralogical and compositional range defined by this suite is represented by Y98. This sample is a porphyritic basalt containing pyroxene and $\mathrm{Fo}_{86}$ olivine that is in equilibrium with the groundmass. This rock is thought to represent a liquid that is in nearequilibrium with its mantle source (Mikouchi et al., 2004; Dalton et al., 2005). It is not surprising, therefore, that the bulk rock is characterized by low abundances of incompatible elements relative to many other shergottites belonging to the suite. In contrast, QUE is a coarse grained porphyritic basalt containing pyroxene, maskelynite, and phosphates with minor abundances of oxides and impact melt glass. The composition of this sample is also thought to represent a melt (McSween et al., 1996). Nevertheless, a low bulk rock Mg\# of 38, the presence of relatively Fe-rich silicates, and high whole rock incompatible element abundances relative to the other shergottites in this suite demonstrate that QUE is significantly more evolved.

Other samples belonging to the depleted shergottite suite, such as NWA1195, DaG, SaU, and Dhofar 019, are basalts that contain variable proportions of olivine, pyroxene, and maskelynite with trace abundances of phosphates, oxides, and impact melt glass (Zipfel et al., 2000; Irving et al., 2002; Taylor et al., 2002). Unfortunately, this set of samples has accumulated variable amounts of olivine, making compositional differences between bulk rocks difficult to interpret. Nevertheless, many characteristics of these samples that are not strongly affected by accumulation are intermediate between Y98 and QUE. For example, the compositions of the olivine, pyroxene, and maskelynite/plagioclase cores in these samples have Mg\#'s and anorthite contents that are in between values observed in Y98 and QUE. Likewise, the Mg\#'s of parental 
liquids calculated from the compositions of olivine cores range from 42 to 56 and are lower than the $\mathrm{Mg} \#$ of $\mathrm{Y} 98$ bulk rock $(\mathrm{Mg} \#=67)$ or its parent calculated from its most mafic olivine composition $(\mathrm{Mg} \#=65)$ and higher than either the value calculated for QUE from the most mafic pigeonite $(\mathrm{Mg} \#=31)$ or the QUE bulk rock $(\mathrm{Mg} \#=38)$.

\subsection{Fractional crystallization models}

Compositional differences observed in the depleted suite of samples may be inherited from their sources and/or reflect elemental fractionation processes that occurred after their primary parental melts left the mantle. The most obvious compositional differences, such as varying $\mathrm{Mg} \#$ of phases and bulk rocks, are consistent with geochemical evolution by fractional crystallization. This is supported by the fact that this suite of meteorites has similar initial $\mathrm{Sr}$ and $\mathrm{Nd}$ isotopic compositions, suggesting that open-system differentiation is not a dominant process responsible for the geochemical variability observed in the suite. As a consequence, major and trace element compositions of this suite are modeled below using closed-system fractional crystallization. Because many of the shergottites have accumulated olivine, pyroxene, and/or plagioclase, only those elemental and mineralogical characteristics that are representative of the parental liquids are considered in the models.

Major element abundances are modeled using the MELTS algorithm (Ghiorso and Sack, 1995) and the REE abundances are modeled using simple fractional crystallization models and mineral modes defined by MELTS. The most primitive sample, Y98, is used as the parent in these calculations. This rock has not accumulated significant amounts of olivine (e.g., Ikeda, 2004) so that the parental melt is represented by the bulk rock composition. Likewise, QUE is thought to represent a near-melt composition (McSween et al., 1996), so that its bulk rock 
composition is also used to represent a liquid. Note that Y98 and QUE have very similar initial Sr and Nd isotopic compositions (Borg et al., 1997; Shih et al., 2005); features that are consistent with evolution from compositionally similar, but not identical, parents by fractional crystallization in a closed system. Importantly, these two samples have different ages so that Y98 cannot be the actual parent of QUE. Rather we postulate that a Y98-like parent could be parental to QUE.

Unfortunately, QUE contains large and variable amounts of phosphates, so that bulk rock REE abundances are not necessarily representative of the melt before crystallization. For example, $\mathrm{Nd}$ abundances reported in the literature vary from 1.4 to $2.4 \mathrm{ppm}$ (Borg et al., 1997; Warren and Kallemeyn, 1997). As a consequence a variety of estimates are used to represent the potential range of QUE parent compositions. These include the whole rock composition from Dreibus et al. (1996) and the bulk rock composition calculated by McSween et al. (1996) from mineral compositions and modes.

\subsubsection{Crystallization sequence}

The bulk composition of Y98 listed in Table 3 is used as the starting composition for the MELTS fractional crystallization model. Fractional crystallization is modeled assuming an anhydrous melt at 1 bar pressure. The $\mathrm{fO}_{2}$ is set in the model at QFM -3 . This $\mathrm{fO}_{2}$ is similar to estimates of magmatic $\mathrm{fO}_{2}$ that are based on compositional systematics of natural and experimentally produced spinels in Y98 (McKay et al., 2004). The liquidus temperature calculated using MELTS for $\mathrm{Y} 98$ is $1430^{\circ} \mathrm{C}$ and is a close match to the experimentally determined liquidus for a similar composition determined by Dalton et al. (2005) at 1 bar pressure. The calculated crystallization sequence is presented in Figure 5. Spinel is the liquidus 
phase followed within $10^{\circ} \mathrm{C}$ by $\mathrm{Fo}_{86}$ olivine. Olivine continues to crystallize until $1320^{\circ} \mathrm{C}$, when orthopyroxene crystallization begins. Orthopyroxene crystallizes until $1220^{\circ} \mathrm{C}$ when pigeonite, followed by high-Ca clinopyroxene at $1150^{\circ} \mathrm{C}$ begin to crystallize. Pigeonite stops crystallizing at $1100^{\circ} \mathrm{C}$, but high-Ca clinopyroxene continues at least until $1000^{\circ} \mathrm{C}$, where the model calculations are terminated. Plagioclase begins to crystallize at $1130^{\circ} \mathrm{C}$ and continues throughout the model run.

The calculated crystallization sequence yields an assemblage that is a close match to the observed petrography of Y980459, which consists of $~ 50 \%$ pyroxene (with sub-equal amounts of orthopyroxene and clinopyroxene), $\sim 10-15 \%$ olivine, and $\sim 30 \%$ liquid (Ikeda, 2004; Greshake

et al., 2004). The models do not crystallize plagioclase until $1130^{\circ} \mathrm{C}$, which is approximately $40^{\circ} \mathrm{C}$ below the QUE liquidus temperature. This is consistent with the absence of plagioclase in Y98, as well as arguments by McSween et al. (1996) that suggested plagioclase did not cocrystallize with pyroxene in QUE.

\subsubsection{Major elements}

Liquid compositions, starting at $\mathrm{Y} 98$, calculated in $10^{\circ} \mathrm{C}$ increments are plotted in Figure 6. The experimentally determined liquidus temperature for QUE is $1170^{\circ} \mathrm{C}$ (Mikouchi et al., 2001) and the composition of the liquid calculated by MELTS at $1170^{\circ} \mathrm{C}$ is a close match to the QUE bulk rock composition. The modeled liquid composition is produced by $43 \%$ fractional crystallization of olivine, orthopyroxene, pigeonite, and spinel from the parent in the proportions 38:40:19:2.

Figure 6 shows that as the $\mathrm{MgO}$ decreases with fractionation, $\mathrm{Al}_{2} \mathrm{O}_{3}, \mathrm{FeO}, \mathrm{CaO}$, and $\mathrm{Na}_{2} \mathrm{O}$ increase. The model reproduces the bulk composition of these elements in QUE within 1 
to 3 percent of the measured value. However, abundances of $\mathrm{P}_{2} \mathrm{O}_{5}$ and $\mathrm{TiO}_{2}$ in the QUE bulk rock are significantly higher than the abundances of these elements calculated by MELTS, whereas the QUE bulk rock abundance of $\mathrm{SiO}_{2}$ is slightly $(\sim 6 \%)$ lower than the abundance calculated by MELTS (Table 3). The elevated bulk rock $\mathrm{P}_{2} \mathrm{O}_{5}$ and $\mathrm{TiO}_{2}$ most likely reflect accumulation of phosphates and ilmenite (the major oxide phase). Likewise low $\mathrm{SiO}_{2}$ determined for the QUE bulk rock could be unrepresentative of the bulk meteorite as a result of the presence of large proportions of phosphate and ilmenite in the small analyzed aliquots.

It is worth noting that two of the largest mismatches $\left(\mathrm{SiO}_{2}\right.$ and $\left.\mathrm{P}_{2} \mathrm{O}_{5}\right)$ between modeled and QUE bulk composition are for the two elements that are most poorly constrained in QUE. For example, $\mathrm{SiO}_{2}$ has been measured only once on material from the interior of QUE (Warren and Kallemeyn, 1997). Furthermore, low $\mathrm{Al}_{2} \mathrm{O}_{3}$ in this analysis relative to other bulk rock analyses (Dreibus et al., 1996; Kring et al., 2003) suggests that this sample had a proportionally lower plagioclase mode. Because plagioclase has relatively high $\mathrm{Si}$, this could partially account for the low $\mathrm{SiO}_{2}$ abundances in this aliquot. Mesostasis containing silica and high Si glass (McSween et al., 1996) might also be under-represented in this aliquot. Likewise, phosphorous has been measured once on interior portions of QUE and twice on fusion crust. These numbers vary significantly from 2.05 to $3.4 \mathrm{wt} \%$ (Mittlefehldt and Lindstrom, 1996; Mikouchi et al., 1996). Phosphorous abundances are also commonly derived by difference and range from 0.13 to $1.74 \mathrm{wt} \%$. This variation ultimately stems from highly variable proportions of phosphate in the analyzed aliquots. Several authors have noted the difficulty of obtaining an aliquot that is truly representative of the whole rock (Kring et al., 2003; McSween et al., 1996; Dreibus et al., 1996). Whatever the case, it is important to keep in mind that we do not propose that Y98 is the direct parent of QUE, but rather that a parent with similar geochemical and isotopic 
characteristics is the parent of QUE.

In order to double check the results of the MELTS calculations, the major element composition of Y980459 has also been reproduced from QUE94201 bulk rock composition (Table 3) by least squared analysis using olivine core compositions and average orthopyroxene composition from Ikeda (2004), and pigeonite composition from Mikouchi et al. (2004). This calculation demonstrates that the bulk composition of Y980459 can be reproduced reasonably well (sum of the residuals squared, $\mathrm{r}^{2}=0.73$ ) from QUE94201 and olivine and pyroxene with compositions similar to those observed in Y980459. This requires $51 \%$ addition of olivine, orthopyroxene, and pigeonite in the proportion 38:33:28 to the QUE94201 bulk composition. This is mathematically analogous to the subtraction of these phases from Y980459. The least squared calculation strongly supports the results of the MELTS calculations because the proportions of phases and amount of fractional crystallization required by the least squared calculation is a close match to values calculated by MELTS.

\subsubsection{Pyroxene compositions}

The composition of pyroxenes calculated by MELTS are presented in Figure 7 along with fields representing pyroxene compositions from Y98 and QUE. Pyroxene core compositions from NWA1195, DaG, SaU, and Dhofar 019 are also plotted on this figure. Note that the modeled pyroxene compositions are a close match to the composition of pyroxenes in Y98. In fact, the most magnesian pyroxene composition calculated by MELTS $\left(\mathrm{En}_{83} \mathrm{Fs}_{16}\right)$ almost exactly matches the most mafic composition observed in $\mathrm{Y} 98\left(\mathrm{En}_{80} \mathrm{Fs}_{18}\right.$; Mikouchi et al., 2004). Also note that the composition of pyroxene in equilibrium with the $1170^{\circ} \mathrm{C}$ QUE-like melt $\left(\mathrm{En}_{62} \mathrm{Fs}_{28}\right)$ is a close match to the most magnesian pyroxene composition observed in QUE ( $\mathrm{En}_{60} \mathrm{Fs}_{31}$; Kring 
et al., 2003). These results indicate that the composition of pyroxene cores in QUE are consistent with formation by fractional crystallization of a Y98-like parental liquid. The differences between pyroxene compositions calculated by MELTS at low temperature and those observed in QUE most likely reflect uncertainties associated with the MELTS calculations at small proportions of liquid.

The most mafic pyroxene core compositions observed in NWA1195, DaG, SaU, and Dhofar 019 also fall along the array of modeled pyroxene compositions (Fig. 7) suggesting that these samples are also related to Y98-like (and QUE-like) magmas by fractional crystallization. Thus, the success of the MELTS calculations in reproducing the majority of mineralogical and elemental characteristics of QUE, as well as the pyroxene compositions of NWA1195, DaG, $\mathrm{SaU}$, and Dhofar 019, suggests that most of the compositional differences between the parental magmas of these samples reflects fractional crystallization from near primary mantle melts with overall geochemical characteristics that are similar to Y98.

\subsubsection{Trace element models}

Trace element models are constructed in order to test whether variations in REE are consistent with the MELTS fractional crystallization models. The models use the bulk rock REE composition of Y98 as the parent. The amount of crystallization and the modes of the fractionating assemblage used in the trace element models are identical to those calculated by MELTS. Thus, the liquid remaining after $43 \%$ crystallization of an assemblage of olivine:orthopyroxene:pigeonite:spinel $=38: 40: 19: 2$ is used to model the REE composition of

QUE. Although, the partition coefficients used in the model are the same as those compiled by 
Borg and Draper (2003) for Mars relevant compositions, the results do not vary significantly because the REEs are in all cases strongly incompatible in the fractionating assemblage.

The model results are compared against the QUE whole-rock REE abundances of Dreibus et al. (1996) and McSween et al. (1996) and are shown in Figure 8. These compositions represent the possible range of REE concentrations in the QUE parental melt. It should be noted, however, that the measured (Dreibus et al., 1996) and calculated (McSween et al., 1996) concentrations of QUE are completely dependent on the abundance of phosphate in the mode. This stems from the simple fact that the vast majority of REEs are hosted in this phase (Wadhwa et al., 1994; 2001).

From Figure 8 it is apparent that the modeled REE pattern is a close match for the pattern of QUE. Furthermore, the abundances of the REE are intermediate between the published whole rock concentrations. Again we attribute discrepancies between the modeled REE concentrations and those observed in the various whole rock measurements to the variable mode of phosphate in the analyzed aliquots. For example, the bulk rock composition of Dreibus et al. (1996) can be reproduced from the modeled melt composition by the addition of $\sim 5 \mathrm{wt} \%$ merrillite (Fig. 8). Addition of 5\% merrillite can also account for the difference between the $\mathrm{P}_{2} \mathrm{O}_{5}$ concentration in the bulk rock and the $\mathrm{P}_{2} \mathrm{O}_{5}$ concentration calculated by MELTS. In fact, the $\mathrm{P}_{2} \mathrm{O}_{5}$ concentration in the modeled liquid will increase from $0.54 \mathrm{wt}$. $\%$ to $2.8 \mathrm{wt} \%$ if $5 \%$ merrillite is added. This is a good match to abundances of $\mathrm{P}_{2} \mathrm{O}_{5}$ determined for some QUE bulk rocks (2.8-3.4 wt. \%; Kring et al., 2003; Mikouchi et al., 1998), as well as the mode of phosphates in QUE (4-6 \%; Mikouchi et al., 1998; Harvey et al., 1996). Other major element concentrations will also vary as a result of phosphate addition. For example, $\mathrm{SiO}_{2}$ decreases by $\sim 2.5 \mathrm{wt} \%$ and matches the measured value, whereas $\mathrm{CaO}$ increases by $\sim 1.5 \mathrm{wt} \%$ and is a poorer match to the measured 
value. All other major elements remain relatively unaffected by the addition of phosphate. Thus, it seems likely that portions of QUE are enriched in phosphates and these phosphates contribute to major and trace element variability observed in measured aliquots. Furthermore, at least some compositional differences observed between the measured whole rocks and calculated modeled melt compositions appear to be consistent with addition of phosphates.

\section{DISCUSSION}

\subsection{Ramifications of the fractional crystallization modeling}

The overall success of the fractional crystallization modeling in reproducing most of the compositional variations observed in the oldest, most LREE-depleted, martian meteorite suite suggests that the mineralogy and major element compositions of these rocks are primarily controlled by fractional crystallization processes. In contrast to the mineralogy and major element compositions, the incompatible trace element systematics, as well as the radiogenic isotope systematics, are dictated by the composition of their source regions (Borg et al., 1997; 2003; Borg and Draper, 2003). We therefore hypothesize that differences in the mineralogical and major element characteristics of the other shergottites that are derived from less LREEdepleted sources are also controlled by crystallization processes. In this view, the total compositional variation observed among the martian basalts would reflect the combined effects of compositional differences in their source regions in addition to fractional crystallization occurring in crustal-level magma chambers. This scenario could account for the observation that indices of differentiation, such as the Mg\# of parental magmas, and incompatible element (Fig. 1) and isotopic systematics of the meteorites do not correlate. It would also indicate that 
assimilation of evolved crustal material by a common parental magma is not required to produce the compositional variations observed in the martian basalt suite.

It is important to note that although the models are able to reproduce most of the characteristics of this suite of meteorites from a common parent (Y98), it is highly unlikely that all of these samples are derived from the same parent. For example, there is an excess of $\mathrm{Hf}$ (and Ti) in QUE that cannot be explained by fractionation from Y98. The phases that control Hf and Ti that are most likely to be involved in shergottite source petrogenesis are garnet and ilmenite (Borg and Draper, 2003). The similar REE patterns of Y98 and QUE indicate that a variable role of garnet in the petrogenesis of these samples is unlikely. Rather, the data seem more consistent with a variable role of ilmenite. If ilmenite is present in higher abundance in the QUE source compared to the Y98 source, then Hf would be expected to be higher in that source. Thus, the sources could have slightly different mineralogies. Alternatively, the sources could be melted to different extents. In the case of the Y98 source, relatively small degrees of melting that leaves ilmenite behind will produce melts with lower Ti and Hf. In the case of QUE, larger degrees of melting could result in complete extraction of ilmenite from the source and melts characterized by higher Ti and Hf. No mater what the melting scenario, it is clear that the Y98 and QUE parental melts are not compositionally identical, and that the observed compositional differences could reflect variable roles of a phase such as ilmenite in their source regions.

In addition, the observations that the depleted shergottites have crystallization ages that span $\sim 250 \mathrm{Ma}$ and have slightly different $\mathrm{Sr}$ and $\mathrm{Nd}$ isotopic systematics, also underscore the idea that these samples do not all derive from the same parent. Rather, the success of the models suggests that numerous parental magmas derived from very similar source regions and having very similar geochemical characteristics have been produced recently in martian history. Thus, a 
source region with geochemical characteristics comparable to Y98 is likely to be large and represent some significant fraction of the martian mantle.

\subsection{Petrogenetic models for shergottite petrogenesis}

A cartoon depicting how the various meteorites could be related to one another is

presented in Figure 9. This cartoon is based on the magma ocean model of martian planetary differentiation presented by Borg et al. (2003) and Borg and Draper (2003). In this model variations in the incompatible-element and isotopic systematics of the shergottites are produced by mixing between depleted martian mantle cumulates that formed relatively early in the magma ocean crystallization sequence and late-stage trapped liquids that solidified in the mantle relatively late. The late-stage material is analogous to lunar KREEP (e.g., Snyder et al., 1992). Thus, the enriched shergottites contain larger proportions of this late-stage trapped material than the depleted shergottites.

Individual samples are associated with individual parental magmas and magma chambers in Figure 9 based on their crystallization ages and incompatible-element and isotopic systematics. Thus, NWA1195 and QUE are depicted as sharing a common magma chamber because they have similar ages and trace-element and isotopic systematics. Likewise, the enriched suite of meteorites with $\sim 175$ Ma ages are inferred to share a common mantle source region and are thus linked to a common magma chamber in Figure 9. Northwest Africa 1068 is the most primitive sample of the enriched suite and is hypothesized to be related to Zagami, NWA856, Los Angeles, and Shergotty by varying degrees of fractional crystallization.

Although the intermediate suite of $\sim 175$ Ma shergottites (EETA/B and the lherzolitic shergottites) are associated with the other $175 \mathrm{Ma}$ shergottites in Figure 9 because of the 
concordance of their crystallization ages, these sample have very different incompatible-element and isotopic systematics (Fig. 4) and must be derived from a different, less incompatibleelement-enriched, mantle source region. Although EETA/B and the lherzolitic shergottites are relatively primitive and have not undergone extensive fractional crystallization from their parents, ALH77005 is the most primitive (parental Mg\#=71) and EETB is the most fractionated of this group (whole-rock Mg\# $=40$ ).

The shergottite NWA1460 has a crystallization age of $352 \mathrm{Ma}$ (Nyquist et al., 2004) and by analogy is probably associated with the igneous complex that contains the other $\sim 340 \mathrm{Ma}$ shergottites. Because NWA1460 belongs to the intermediate suite of meteorites, it ultimately must be derived from a different mantle source region than the LREE-depleted $340 \mathrm{Ma}$ shergottites. The fact that both the 340 and the 175 Ma shergottites contain samples that are derived from multiple source regions implies that individual magmatic systems on Mars are recharged from compositionally distinct source regions.

The oldest shergottites (Y98, DaG, Dhofar 019, and SaU) are members of the depleted suite and consequently are associated with this magmatic complex in Figure 9. There is no physical evidence that suggests that these meteorites are derived from the same complex. They are simply combined because they share geochemical and isotopic features. Alternatively, the depleted samples of various ages could be from different magmatic complexes, but derived from a fairly homogeneous, regionally extensive mantle source region.

The scenario described above, in which compositional variation is produced by the combined effects of source heterogeneity and fractional crystallization, predicts that the mineralogy and major element compositions of other suites of meteorites that share a common source region should also be related by fractional crystallization. In principle this can be tested 
using samples such as NWA1068/1110, NWA856, Los Angeles, Zagami, and Shergotty that have very similar REE and Sr-Nd isotopic systematics, but have different mineralogies and major element compositions. Based on the concepts and models presented in this paper, these samples are predicted to be related to a common parent by fractional crystallization. Accumulation of phases in these sample makes this hypothesis difficult to test because the major and REE parental melt compositions are not precisely known. This is particularly true for the most mafic sample from this suite, NWA1068/1110. Ultimately, rigorous testing of this hypothesis may have to wait until a primitive parental melt composition is defined for this suite (e.g., NWA1068) or a primitive sample like Y98 that has REE and Sr-Nd isotopic systematics similar to this incompatible-element-enriched suite of samples is found.

As discussed above, the isotopic systematics of the martian meteorites require highly depleted and enriched source regions to form early in the history of Mars and remain isolated until relatively recently when magma production occurred. At the same time, the young ages of the martian meteorites indicate that there is recent volcanism on the planet and imply that the martian mantle has been convecting for much of its history. These observations are perhaps the strongest argument that the enriched component observed in the martian meteorites is located in the crust. The disadvantage of this scenario is twofold. First, it does not account for the lack of geochemical evidence for $\mathrm{AFC}$, and second it places most of the heat producing elements in the crust seemingly prohibiting convection. On the other hand, if the enriched component is in the mantle, then a mechanism to isolate this component from its depleted counterpart until the time of magma production is required. Thus, either some portion of the mantle is not convecting and has consequently remained isolated, or the convection process has not completely homogenized the mantle. In either case, the location of the enriched component remains an outstanding 
problem in martian geology with profound implications for the past and present physical state of Mars.

\section{CONCLUSION}

The Sm-Nd isotopic systematics define a $348 \pm 19$ Ma crystallization age and an $\varepsilon_{N d}^{143}$ value of $+40.1 \pm 1.3$ for basaltic shergottite NWA1195. The large positive $\varepsilon_{N d}^{143}$ value and relatively young crystallization age indicates that NWA1195, like other depleted shergottites, was derived from a source region characterized by a long-term light rare earth element depletion. We observe that the olivine fraction is in isotopic equilibrium with other fractions which suggests that the olivine megacrysts in NWA1195 could be true phenocrysts. The maskelynite fractions appear to contain a LREE-enriched component that may have been added during the shock event(s) that generated the maskelynite. This component appears to also be present in QUE and have only affected the maskelynite in both meteorites. Presumably this is because of the low REE abundances in plagioclase and more open-system response to shock of plagioclase compared to pyroxenes. Although the $\mathrm{Rb}-\mathrm{Sr}$ system is disturbed, most likely as a result of terrestrial $\mathrm{Sr}$ contamination, an initial ${ }^{87} \mathrm{Sr} /{ }^{86} \mathrm{Sr}$ ratio of $0.701614 \pm 16$ is estimated. Despite the fact that this value represents an upper limit, it is consistent with the Sm-Nd isotopic analyses and suggests that the NWA1195 source region is characterized by a long-term incompatible element depletion.

Northwest Africa 1195 shares many geochemical features with other LREE-depleted shergottites including early crystallizing mafic phases, radiogenic $\mathrm{Nd}$ and un-radiogenic Sr initial isotopic compositions, and old crystallization ages between 327 and $575 \mathrm{Ma}$. The most depleted shergottites appear to be related to each other via simple, closed-system fractional crystallization. 
Starting with the primitive member of this suite, Y98, it is possible to reproduce many of the characteristics of the most evolved member, QUE, using the MELTS algorithm. This requires approximately $43 \%$ fractional crystallization of olivine, pyroxene and traces of spinel. In addition, the REE systematics of QUE are reproduced reasonably well by fractional crystallization of olivine and pyroxene in the proportions determined by the MELTS algorithm. The success of the fractional crystallization models suggests that the shergottites do not evolve by simple AFC in the martian crust. Instead, compositional variations observed in the shergottites appear to reflect fractional crystallization of magmas derived from compositionally distinct source regions.

Acknowledgments - We would like to thank D. Mittlefehldt for editorial handling and Jean-Alix Barrat, Chris Herd, and Dimitri Papanastassiou for their insightful reviews. We would also like to thank Amy Gaffney for her help with the MELTS calculations and several discussions. This work was supported by NASA grant NNG05GF83G to LEB. Part of the work performed by LEB was under the auspices of the U. S. Department of Energy by the University of California, Lawrence Livermore National Laboratory under Contract No. W-7405-Eng-48. This study made use of NASA's Astrophysics Data System Abstract Service and the Mars Meteorite Compendium compiled by Charles Meyer.

Associate Editor: D. Mittlefehldt 


\section{References}

Anders E. and Grevesse N. (1989) Abundances of the elements: Meteoritic and solar. Geochim. Cosmochim. Acta 53, 197-214.

Barrat J. A., Gillet Ph., Sautter V., Jambon A., Javoy M., Göpel C., Keller F. and Petit E. (2001) The basaltic shergottite Northwest Africa 480: Petrology and geochemistry. Meteor. Planet. Sci. 36, A14 (abstr.).

Barrat J. A., Jambon A., Bohn M., Gillet Ph., Sautter V., Göpel C., Lesourd M. and Keller F. (2002) Petrology and chemistry of the picritic shergottite North West Africa 1068 (NWA 1068). Geochim. Cosmochim. Acta 66, 3505-3518.

Borg L. E. and Drake M. J. (2005) A Review of Meteorite Evidence for the Timing of Magmatism and of Surface or Near-Surface Liquid Water on Mars. J. Geophys. Res. 110, E12SO3, doi:10.1029/2005JE002402

Borg L. E. and Draper D. A. (2003) A petrogenetic model for the origin and compositional variation of the martian basaltic meteorites. Meteor. Planet. Sci. 38, 1713-1731.

Borg L. E., Nyquist L. E., Wiesmann H. and Shih C. -Y. (1997) Constraints on Martian differentiation processes from $\mathrm{Rb}-\mathrm{Sr}$ and $\mathrm{Sm}-\mathrm{Nd}$ isotopic analyses of the basaltic shergottite QUE94201. Geochim. Cosmochim. Acta 61, 4915-4931. 
Borg L. E., Connelly J. N, Nyquist L. E., Shih C. -Y., Wiesmann H. and Reese Y. (1999) The age of the carbonates in martian meteorite ALH84001. Science 286, 90-94.

Borg L. E., Nyquist L. E., Reese Y., Wiesmann H., Shih C. -Y. , Ivanova M., Nazarov M. A. and Taylor L. A. (2001) The age of Dhofar 019 and its relationship to the other Martian meteorites. Lunar Planet. Sci. XXXII. Lunar Planet. Inst., Houston. \#1144 (abstr.).

Borg L. E., Nyquist L. E., Wiesmann H. and Reese Y. (2002) Constraints on the petrogenesis of martian meteorites from $\mathrm{Rb}-\mathrm{Sr}$ and $\mathrm{Sm}-\mathrm{Nd}$ isotopic systematics of the lherzolitic shergottites ALH77005 and LEW88516. Geochim. Cosmochim. Acta 66, 2037-2053.

Borg L. E., Nyquist L. E., Wiesmann H., Shih C. -Y. and Reese Y. (2003) The Age of Dar al Gani 476 and the Differentiation History of the Martian Meteorites Inferred from their Radiogenic Isotopic Systematics. Geochim. Cosmochim. Acta 67, 3519-3536.

Borg L. E., Edmunson J. E. and Asmerom Y. (2005) Constraints on the U-Pb isotopic systematics of Mars inferred from a combined $\mathrm{U}-\mathrm{Pb}, \mathrm{Rb}-\mathrm{Sr}$, and $\mathrm{Sm}-\mathrm{Nd}$ isotopic study of the Martian meteorite Zagami. Geochim. Cosmochim. Acta 69, 5819-5830.

Brandon A. D., Nyquist L. E., Shih C. -Y. and Wiesmann H. (2004) Rb-Sr and Sm-Nd Isotope Systematics of Shergottite NWA 856: Crystallization Age and Implications for Alteration of Hot Desert SNC Meteorites. Lunar Planet. Sci. XXXV. Lunar Planet. Inst., Houston. \#1931 (abstr.). 
Burgess K. D., Musselwhite D. S. and Treiman A. H. (2006) Experimental petrology of olivinephyric shergottite NWA 1068: Toward defining a parental melt. Lunar Planet. Sci. XXXVII. Lunar Planet. Inst., Houston. \#1972 (abstr.).

Dalton H. A., Musselwhite D. S., Kiefer W. and Treiman A. H. (2005) Experimental petrology of the basaltic shergottite Yamato 980459: Implications for the thermal structure of the martian mantle. Lunar Planet. Sci. XXXVI. Lunar Planet. Inst., Houston. \#2142 (abstr.).

Dreibus G., Spettel B., Wlotzka F., Schultz L., Weber H. W., Jochum K. P. and Wänke H. (1996) QUE94201: An unusual Martian basalt. Meteor. Planet. Sci. 31, A39-40 (abstr.).

Dreibus G., Spettel B., Haubold R., Jochum K. P., Palme H., Wolf D. and Zipfel J. (2000) Chemistry of a new shergottite: Sayh al Uhaymir 005. Meteor. Planet. Sci. 35, A49 (abstr.).

Dreibus G., Wlotzka F., Huisl W., Jagoutz E., Kubny A. and Spettel B. (2002) Chemistry and petrology of the most feldspathic shergottite: Dhofar 378. Meteor. Planet. Sci. 37, A43 (abstr.).

Edmunson J., Borg L. E., Shearer C. K. and Papike J. J. (2005) Defining the mechanisms that disturb the Sm-Nd isotopic systematics of martian meteorites: Examples from Dar al Gani 476 and Allan Hills 77005. Meteor. Planet. Sci. 40, 1159-1174. 
Ghiorso M. S. and Sack R. O. (1995) Chemical mass transfer in magmatic processes IV. A revised and internally consistent thermodynamic model for the interpolation and extrapolation of liquid-solid equilibria in magmatic systems at elevated temperatures and pressures. Contrib. Mineral. Petrol. 119, 197-212.

Greshake A., Fritz J. and Stöffler D. (2004) Petrology and shock metamorphism of the olivinephyric shergottite Yamato 980459: Evidence for a two-stage cooling and a single-stage ejection history. Geochim. Cosmochim. Acta 68, 2359-2377.

Harvey R. P., McCoy T. J. and Leshin L. A. (1996) Shergottite QUE94201: Texture, mineral compositions, and comparison with other basaltic shergottites. Lunar Planet. Sci. XXVII. Lunar Planet. Inst., Houston. 497-498 (abstr.).

Herd C. D. K., Borg L. E. and Papike J. J. (2002) Systematics of oxygen fugacity and geochemical variations in the martian basalts: Implications for martian basalt petrogenesis and oxidation state of the upper mantle of Mars. Geochim. Cosmochim. Acta 66, 2025-2036.

Ikeda Y. (2004) Petrology of the Yamato 980459 shergottite. Antarct. Meteorite Res. 17, 35-54. 
Irving A. J., Kuehner S. M., Hupe A. C. and Hupe G. M. (2002) Olivine-phyric basaltic shergottite NWA1195: A very primitive martian lava. Meteor. Planet. Sci. 37, A69 (abstr.).

Irving A. J, Bunch T. E., Kuehner S. M. and Wittke J. H. (2004) Petrology of primitive olivineorthopyroxene-phyric shergottites NWA 2046 and NWA 1195: Analogies with terrestrial boninites and implications for partial melting of hydrous martian mantle. Lunar Planet. Sci. XXXV. Lunar Planet. Inst., Houston. \#1444 (abstr.).

Jambon A., Barrat J. A., Sautter V., Gillet Ph., Göpel C., Javoy M., Joron J-L. and Lesord M. (2002) The basaltic shergottite Northwest Africa 856: Petrology and chemistry. Meteor. Planet. Sci. 37, 1147-1164.

Jones J. H. (1989) Isotopic relationships among the Shergottites, Nakhlites and Chassigny. Proc. 19th Lunar Planet Sci. Conf. 465-474.

Kring D. A., Gleason J. D., Swindle T. D., Nishiizumi K., Caffee M. W., Hill D. H., Jull A. J. T. and Boynton W. V. (2003) Composition of the first bulk melt sample from a volcanic region of Mars: Queen Alexandra Range 94201. Meteor. Planet. Sci. 38, 1833-1848.

Lodders K. (1998) A survey of shergottite, nakhlite and chassigny meteorites whole-rock compositions. Meteor. Planet. Sci. 33, A183-A190. 
Longhi J. and Pan V. (1989) The parent magmas of the SNC meteorites. Proc. Lunar Planet. Sci. Conf. 19th, 451-464. Lunar Planetary Institute, Houston.

McKay G. A., Yang S. -R. and Wagstaff J. (1996) Complex zoned pyroxenes in shergottite QUE94201: Evidence for a two-stage crystallization history. Lunar Planet. Sci. XXVII. Lunar Planet. Inst., Houston. 851-852 (abstr.).

McKay G., Mikouchi T., Schwandt C. and Lofgren G. (1998) Fracture fillings in ALH84001 feldspathic glass: Carbonate and silica. Lunar Planet. Sci. XXIX. Lunar Planet. Inst., Houston. \#1944 (abstr.).

McKay G., Le L., Schwandt C., Mikouchi T., Koizumi E. and Jones J. (2004) Yamato 980459: The most primitive shergottite? Lunar Planet. Sci. XXXV. Lunar Planet. Inst., Houston. \#2154 (abstr.).

McSween, Jr., H. Y. (1994) What we have learned about Mars from SNC meteorites. Meteor. Planet. Sci. 29, 757-779.

McSween, Jr., H. Y., Eisenhour D. D., Taylor L. A., Wadhwa M. and Crozaz G. (1996) QUE94201 shergottite: Crystallization of a Martian basaltic magma. Geochim. Cosmochim. Acta 60, 4563-4569. 
McSween, Jr., H. Y., Grove T. L. and Wyatt M. B. (2003) Constraints on the composition and petrogenesis of the Martian crust. J. Geophys. Res. 108, 9-19.

Mikouchi T., Miyamoto M. and McKay G. (1998) Mineralogy of Antarctic basaltic shergottite Queen Alexandra Range 94201: Similarities to Elephant Moraine A79001 (Lithology B) martian meteorite. Meteor. Planet. Sci. 33, 181-189.

Mikouchi T., Koizumi E., McKay G., Le L. and Schwandt C. (2001) Experimental crystallization of the QUE94201 basaltic shergottite. Lunar Planet. Sci. XXXII. Lunar Planet. Inst., Houston. \#2100 (abstr.).

Mikouchi T., Koizumi E., McKay G., Monkawa A., Ueda Y., Chokai J. and Miyamoto M. (2004) Yamato 980459: Mineralogy and petrology of a new shergottite-related rock from Antarctica. Antarct. Meteorite Res. 17, 13-34.

Mittlefehldt D. W. and Lindstrom M. M. (1996) Martian meteorites QUE 94201, an unusual basalt, and Governador Valadares, a typical clinopyroxenite: Geochemistry. Lunar Planet. Sci. XXVII. Lunar Planet. Inst., Houston. 887-888 (abstr.).

Nyquist L. E., Borg L. E. and Shih C-. Y. (1998) The shergottite age paradox and the relative probabilities for Martian meteorites of differing ages. J. Geophys. Res. 103, 3144531455. 
Nyquist L. E., Bogard D. D., Shih C. -Y., Greshake A., Stöffler D. and Eugster O. (2001) Ages and histories of martian meteorites. In Chronology and Evolution of Mars (eds. Kallenbach R., Geiss J. and Hartmann W. K.) Springer, pp. 105-164.

Nyquist L. E., Shih C. -Y., Reese Y. D. and Irving A. J. (2004) Crystallization age of NWA1460: Paradox revisited. Second Conf. Early Mars, Abstract \#8041.

Schaaf P. and Müller-Sohnius D. (2002) Strontium and neodymium isotopic study of Libyan desert glass: Inherited Pan-African age signatures and new evidence for target material. Meteor. Planet. Sci. 37, 565-576.

Shih C. -Y., Nyquist L. E., Wiesmann H., Reese Y. and Misawa K. (2005) Rb-Sr and Sm-Nd dating of olivine-phyric shergottite Yamato 980459; Petrogenesis of depleted shergottites. Antarct. Meteor. Res. 18, 46-65.

Shih C. -Y., Nyquist L. E. and Reese Y. (2007) Rb-Sr and Sm-Nd isotopic studies of martian depleted shergottites SaU 094/005. Lunar Planet. Sci. XXXVIII. Lunar Planet. Inst., Houston. \#1745 (abstr.).

Shirai N. and Ebihara M. (2004) Chemical characteristics of a martian meteorite, Yamato 980459. Antarct. Meteorite Res. 17, 55-67. 
Snyder G. A., Taylor L. A. and Neal C. R. (1992) A chemical model for generating the source of mare basalts: Combined equilibrium and fractional crystallization of the lunar magmashpere. Geochim. Cosmochim. Acta 56, 3809-3823.

Taylor L. A., Nazarov M. A., Shearer C. K., McSween, Jr., H. Y., Cahill J., Neal C. R., Ivanova M. A., Barsukova L. D., Lentz R. C., Clayton R. N. and Mayeda T. K. (2002) Martian meteorite Dhofar 019: A new shergottite. Meteor. Planet. Sci. 37, 1107-1128.

Treiman A. H. and Sutton S. R. (1992) Petrogenesis of the Zagami meteorite: Inferences from synchrotron X-ray (SXRF) microprobe and electron microprobe analyses of pyroxenes. Geochim. Cosmochim. Acta 56, 4059-4074.

Wadhwa M., McSween, Jr., H. Y. and Crozaz G. (1994) Petrogenesis of shergottite meteorites inferred from minor and trace element microdistributions. Geochim. Cosmochim. Acta 58, 4213-4229.

Wadhwa M., Lentz R. C. F., McSween, Jr., H. Y. and Crozaz G. (2001) A petrologic and trace element study of Dar al Gani 476 and Dar al Gani 489: Twin meteorites with affinities to basaltic and lherzolitic shergottites. Meteor. Planet. Sci. 36, 195-208.

Warren P. H. and Kallemeyn G. W. (1997) Yamato-793605, EET79001, and other presumed martian meteorites: Compositional clues to their origins. Antarct. Meteorite Res. 10, 6181. 
Zipfel J., Scherer P., Spettel B., Dreibus G. and Schultz L. (2000) Petrology and chemistry of the new shergottite Dar al Gani 476. Meteor. Planet. Sci. 35, 95-106. 
Table 1. NWA1195 Sm-Nd isotopic data

\begin{tabular}{|c|c|c|c|c|c|c|c|}
\hline Fraction & $\begin{array}{l}\text { Mass } \\
(\mathrm{mg})\end{array}$ & $\begin{array}{c}\mathrm{Sm} \\
(\mathrm{ppm})\end{array}$ & $\begin{array}{l}\text { Sm } \\
\text { (ng) }\end{array}$ & $\begin{array}{c}\mathrm{Nd} \\
(\mathrm{ppm})\end{array}$ & $\begin{array}{l}\mathrm{Nd} \\
(\mathrm{ng})\end{array}$ & $\frac{{ }^{147} S m^{\mathrm{a}}}{{ }^{144} N d}$ & $\frac{{ }^{143} N d}{{ }^{144} N d}$ \\
\hline Wr 1 & 19.82 & 0.254 & 5.0 & 0.295 & 5.8 & $0.54220 \pm 54$ & $0.515476 \pm 10$ \\
\hline $\mathrm{Wr} 2$ (R) & 63.82 & 0.083 & 5.3 & 0.066 & 4.2 & $0.79778 \pm 80$ & $0.516052 \pm 21$ \\
\hline Mask 1 (R) & 6.83 & 0.050 & 0.34 & 0.060 & 0.41 & $0.52840 \pm 598$ & $0.514988 \pm 57$ \\
\hline Mask 2 (R) & 11.82 & 0.046 & 0.54 & 0.063 & 0.74 & $0.46164 \pm 304$ & $0.514851 \pm 60$ \\
\hline $\mathrm{Mg}-\mathrm{Px} 1(\mathrm{R})$ & 49.10 & 0.098 & 4.8 & 0.073 & 3.6 & $0.84396 \pm 97$ & $0.516163 \pm 10$ \\
\hline Mg-Px $2(\mathrm{R})$ & 10.86 & 0.086 & 0.94 & 0.059 & 0.64 & $0.91773 \pm 574$ & $0.516249 \pm 58$ \\
\hline $\mathrm{Fe}-\mathrm{Px}(\mathrm{R})$ & 21.40 & 0.100 & 2.1 & 0.078 & 1.7 & $0.81698 \pm 198$ & $0.516118 \pm 11$ \\
\hline Olivine & 70.26 & 0.028 & 1.9 & 0.027 & 1.9 & $0.64753 \pm 145$ & $0.515730 \pm 11$ \\
\hline
\end{tabular}

\begin{tabular}{lll}
\hline LaJolla Nd $(\mathrm{N}=4)$ & 10 & $0.511838 \pm 22^{\mathrm{c}}$ \\
\hline
\end{tabular}

$\overline{\mathrm{Wr}}=$ whole rock, $\mathrm{Px}=$ pyroxene, Mask = maskelynite, $\mathrm{R}=$ residue after leaching in acetic/HCl. All samples and standards run as $\mathrm{NdO}^{+}$.

a. Error limits apply to last digits and include a minimum uncertainty of $0.5 \%$ plus $50 \%$ of the blank correction for $\mathrm{Sm}$ and $\mathrm{Nd}$ added quadratically.

b. Normalized to ${ }^{146} \mathrm{Nd} /{ }^{144} \mathrm{Nd}=0.7219$. Uncertainties refer to last digits and are $2 \sigma_{\mathrm{m}}$ calculated from the measured isotopic ratios. $2 \sigma_{m}=\left[\Sigma\left(m_{i}-\mu\right)^{2} /(n(n-1))\right]^{1 / 2}$ for $n$ ratio measurements $m_{i}$ with mean value $\mu$.

c. Error limits refer to last digits and are $2 \sigma_{\mathrm{p}} .2 \sigma_{\mathrm{p}}=\left[\Sigma\left(\mathrm{M}_{\mathrm{i}}-\pi\right)^{2} /(\mathrm{N}-1)\right]^{1 / 2}$ for $\mathrm{N}$ measurements $\mathrm{M}_{\mathrm{i}}$ with mean value $\pi$.

Isochrons are calculated using either $2 \sigma_{\mathrm{p}}$ (from standard runs) or $2 \sigma_{\mathrm{m}}$ (from measured isotopic ratios), whichever is larger. 
Table 2. NWA1195 Rb-Sr isotopic data

\begin{tabular}{lccccccc}
\hline Fraction & $\begin{array}{c}\text { Mass } \\
(\mathrm{mg})\end{array}$ & $\begin{array}{c}\mathrm{Rb} \\
(\mathrm{ppm})\end{array}$ & $\begin{array}{c}\mathrm{Rb} \\
(\mathrm{ng})\end{array}$ & $\begin{array}{c}\mathrm{Sr} \\
(\mathrm{ppm})\end{array}$ & $\begin{array}{c}\mathrm{Sr} \\
(\mathrm{ng})\end{array}$ & ${ }^{87} \mathrm{Rb}{ }^{\mathrm{a}}$ & ${ }^{86} \mathrm{Sr}$ \\
\hline Wr 1 & 19.82 & 0.374 & 7.4 & 19.20 & 380 & $0.05638 \pm 56$ & $0.705141 \pm 10$ \\
Wr 2 (R) & 63.82 & 0.398 & 25.4 & 26.22 & 1673 & $0.04391 \pm 44$ & $0.703969 \pm 10$ \\
Mask 1 (R) & 6.83 & 0.484 & 3.3 & 72.47 & 495 & $0.01933 \pm 19$ & $0.701868 \pm 10$ \\
Mask 2 (R) & 11.82 & 0.662 & 7.8 & 87.46 & 1034 & $0.02191 \pm 22$ & $0.701721 \pm 10$ \\
Mg-Px 1 (R) & 49.10 & 0.323 & 15.9 & 22.49 & 1104 & $0.04159 \pm 42$ & $0.705535 \pm 10$ \\
Mg-Px 2 (R) & 10.86 & 0.271 & 2.9 & 19.64 & 213 & $0.04001 \pm 48$ & $0.705781 \pm 10$ \\
Fe-Px (R) & 21.40 & 0.308 & 6.6 & 17.04 & 365 & $0.05223 \pm 130$ & $0.706717 \pm 10$ \\
Olivine & 70.26 & 0.213 & 15.0 & 7.44 & 523 & $0.08296 \pm 83$ & $0.707265 \pm 11$
\end{tabular}

NBS-987 $(\mathrm{N}=7)$ $0.710261 \pm 28^{\mathrm{c}}$

$\mathrm{Wr}=$ whole rock, $\mathrm{Px}=$ pyroxene, Mask = maskelynite, $\mathrm{R}=$ residue after leaching in acetic/HCl.

${ }^{85} \mathrm{Rb} /{ }^{87} \mathrm{Rb}$ ratio of six runs of the NBS-984 Rb standard $=2.624 \pm 20\left(2 \sigma_{\mathrm{p}}\right)$.

a. Error limits $(2 \sigma)$ apply to last digits and include a minimum uncertainty of $1 \%$ plus $50 \%$ of the blank correction for $\mathrm{Rb}$ and $\mathrm{Sr}$ added quadratically.

b. Normalized to ${ }^{86} \mathrm{Sr} /{ }^{88} \mathrm{Sr}=0.1194$. Uncertainties refer to last digits and are $2 \sigma_{\mathrm{m}}$ calculated from the measured isotopic ratios. $2 \sigma_{m}=\left[\Sigma\left(m_{i}-\mu\right)^{2} /(n(n-1))\right]^{1 / 2}$ for $n$ ratio measurements $m_{i}$ with mean value $\mu$.

c. Uncertainties refer to last digits and are $2 \sigma_{\mathrm{p}} .2 \sigma_{\mathrm{p}}=\left[\Sigma\left(\mathrm{M}_{\mathrm{i}^{-}} \pi\right)^{2} /(\mathrm{N}-1)\right]^{1 / 2}$ for $\mathrm{N}$ measurements $\mathrm{M}_{\mathrm{i}}$ with mean value $\pi$.

Isochrons are calculated using either $2 \sigma_{\mathrm{p}}$ (from standard runs) or $2 \sigma_{\mathrm{m}}$ (from measured isotopic ratios), whichever is larger. 
Table 3. Major element data for Y980459, QUE94201, modeled melts, and minerals

\begin{tabular}{|c|c|c|c|c|c|c|c|}
\hline & $\begin{array}{c}\text { Y980459 } \\
\text { Bulk } \\
\text { Rock } \\
{[1]}\end{array}$ & $\begin{array}{l}\text { Y980459 }^{\mathrm{a}} \\
\text { calculated } \\
\text { least } \\
\text { squares }\end{array}$ & $\begin{array}{c}\text { Y980459 } \\
\text { avg olivine } \\
{[2]}\end{array}$ & $\begin{array}{c}\text { Y980459 } \\
\text { avg opx } \\
{[2]}\end{array}$ & $\begin{array}{c}\text { Y980459 } \\
\text { avg pig } \\
{[3]}\end{array}$ & $\begin{array}{c}\text { QUE 94201 } \\
\text { Bulk Rock } \\
\text { Range } \\
{[4-7]}\end{array}$ & $\begin{array}{l}1170^{\circ} \mathrm{C} \\
\text { MELT }^{b}\end{array}$ \\
\hline Mg\# bulk rock & 66.9 & 67.3 & & & & 38.0 & 38.2 \\
\hline $\mathrm{SiO}_{2}$ & 48.77 & 48.79 & 39.89 & 55.23 & 53.41 & 47.92 & 50.64 \\
\hline $\mathrm{TiO}_{2}$ & 0.54 & 1.01 & & 0.02 & 0.12 & $1.7-1.98$ & 0.83 \\
\hline $\mathrm{Al}_{2} \mathrm{O}_{3}$ & 5.28 & 5.07 & & 0.44 & 0.89 & $9.83-12$ & 9.91 \\
\hline $\mathrm{Cr}_{2} \mathrm{O}_{3}$ & 0.71 & & & & & $0.13-0.15$ & 0.18 \\
\hline $\mathrm{FeO}$ & 17.35 & 17.07 & 14.68 & 13.69 & 16.75 & $17.73-19.17$ & 18.12 \\
\hline $\mathrm{MnO}$ & 0.52 & 0.46 & 0.26 & 0.44 & 0.65 & $0.44-0.47$ & 0.60 \\
\hline $\mathrm{MgO}$ & 19.67 & 19.74 & 44.24 & 27.13 & 21.28 & $5.8-6.3$ & 6.27 \\
\hline $\mathrm{CaO}$ & 6.38 & 6.78 & 0.11 & 1.82 & 5.28 & $10.63-11.47$ & 11.46 \\
\hline $\mathrm{Na}_{2} \mathrm{O}$ & 0.48 & 0.71 & & 0.03 & 0.04 & $1.39-1.87$ & 1.41 \\
\hline $\mathrm{K}_{2} \mathrm{O}$ & 0.02 & & & & & $0.04-0.07$ & 0.04 \\
\hline $\mathrm{P}_{2} \mathrm{O}_{5}$ & 0.29 & & & & & $2.05^{\mathrm{c}}$ & 0.54 \\
\hline Total & 100.00 & 99.63 & 99.18 & 98.80 & 98.42 & & 100.00 \\
\hline
\end{tabular}

a. Y980459 composition calculated by least squares addition of olivine, orthopyroxene (opx), and pigeonite (pig) compositions in this table.

b. $1170^{\circ} \mathrm{C}$ melt calculated using MELTS assuming fractional crystallization of $\mathrm{Y} 980459$ at 1 bar pressure and $\mathrm{fO}_{2}=$ QFM -3.

c See text for discussion of range for this element.

Refs. [1] Misawa (2004); data normalized to 100, [2] Ikeda (2004), [3] Mikouchi et al. (2004), [4] Dreibus et al. (1996), [5] Warren and Kallemeyn (1997), [6] Kring et al. (2003), [7] Mittlefehldt and Lindstrom (1996). 


\section{Figure Captions}

Figure 1. Whole-rock values of chondrite normalized $\mathrm{La} / \mathrm{Yb}$ ratios $\mathrm{vs}$. $\mathrm{Mg \#}$ $\left(=[\mathrm{MgO} /(\mathrm{MgO}+\mathrm{FeO})]_{\text {molar }}\right)$ of shergottite whole-rocks or calculated for shergottite parental liquids. Symbols correspond to subgroup classification: triangles are samples that have isotopic and rare-earth element systematics indicative of derivation from incompatible-element-depleted source regions, circles are derived from incompatible-element-enriched source regions, and squares are derived from source regions with intermediate incompatible-element systematics (see text). Many of these samples are partial cumulates so that the plotted parental liquid $\mathrm{Mg \#}$ was either calculated from their olivine compositions using $\mathrm{KD}^{\mathrm{FeO} / \mathrm{MgO}}=0.30$ (meteorite names with Ol) or were derived from their estimated parental liquid bulk compositions (solid symbols; Longhi and Pan, 1989; Treiman and Sutton, 1992; Burgess et al., 2006). Meteorite names with $\left(\mathrm{Wr}^{*}\right)$ after them are samples that are thought to represent a liquid composition. Meteorite names with (Wr) after them are plotted using whole-rock Mg\# values. These (Wr) values may shift $~ 10-20 \mathrm{Mg} \#$ units lower depending on the amount of mafic phases they have accumulated. Note that there is no correlation between degree of LREE-enrichment and degree of differentiation.

Figure 2. Sm-Nd isochron diagram for NWA1195. The crystallization age of NWA1195 is 348

$\pm 19 \mathrm{Ma}$ and is defined by two whole-rock fractions and three mineral separates including olivine and two pyroxene fractions. The presence of a relatively low $\mathrm{Sm} / \mathrm{Nd}$ component in the olivine fraction is indicated by its position on the isochron. This component is most likely melt inclusions (e.g. Edmunson et al., 2005). The symbol (R) denotes residue remaining after leaching in acetic/HCl acids. Mask $1(\mathrm{R})$, Mask $2(\mathrm{R})$, and Mg-Px 2 (R) do not lie on the 
isochron and were not used to define the age. The initial ${ }^{143} \mathrm{Nd} /{ }^{144} \mathrm{Nd}$ ratio yields an $\varepsilon_{N d}^{143}$ value of $+40.1 \pm 1.3$ for the source region. Inset shows deviation of individual points from the isochron in $\varepsilon$ units.

Figure 3. Rb-Sr isochron diagram of mineral fractions from NWA1195. The data do not define an isochron and no meaningful age data is obtained. Dotted line is a linear regression through five of the fractions and corresponds to an age of $6.0 \mathrm{Ga}$. Like other hot desert finds, the Rb-Sr system of NWA1195 is disturbed, most likely as a result of contamination by terrestrial Sr. Libyan desert sandstones have ${ }^{87} \mathrm{Sr} /{ }^{86} \mathrm{Sr}$ values of $\sim 0.709$ (Schaaf and Müller-Sohnius, 2002) which is a good representation of the composition of the terrestrial contaminant. An estimate of the initial ${ }^{87} \mathrm{Sr} /{ }^{86} \mathrm{Sr}$ ratio of $0.701614 \pm 16$ is obtained for NWA1195 by fitting a $348 \mathrm{Ma}$ reference isochron through the Mask 2 (R) fraction which appears to be least affected by contamination.

Figure 4. Present-day ${ }^{87} \mathrm{Sr} /{ }^{86} \mathrm{Sr}-\varepsilon_{N d}^{143}$ plot of shergottite source regions illustrating three distinct suites of samples. Filled triangles are the oldest shergottites with strongly LREE-depleted REE patterns. Inset A depicts REE patterns of these samples plotted in order of increasing abundance: DaG476, Y980459, Dhofar 019, and QUE94201. A complete pattern for NWA1195 is not available, but the Sm and $\mathrm{Nd}$ abundances derived from the present study are included as asterisks in Inset A. Solid squares are shergottites with intermediate REE and Sr-Nd isotopic systematics. Inset B depicts REE patterns of these samples plotted in order of increasing abundance: LEW88516, ALH77005, EET79001 lithology A, NWA1460, and EET79001 lithology B. Filled circles are $\sim 175$ Ma shergottites with the most enriched LREE patterns and sources with the 
most radiogenic $\mathrm{Sr}$ and least radiogenic $\mathrm{Nd}$ isotopic compositions. Inset $\mathrm{C}$ depicts $\mathrm{REE}$ patterns of these samples plotted in order of increasing abundance: Zagami, NWA1068, NWA856, Shergotty, and Los Angeles. All REE abundances normalized to values of Anders and Grevesse (1989). Isotopic compositions of sources are calculated assuming a two stage evolutionary model in which $\mathrm{Sr}$ and $\mathrm{Nd}$ evolved from the solar system initial values in an undifferentiated reservoir with ${ }^{87} \mathrm{Rb} /{ }^{86} \mathrm{Sr}$ ratio of 0.16 (Borg et al., 1997) and a chondritic ${ }^{147} \mathrm{Sm} /{ }^{144} \mathrm{Nd}$ ratio until 4.524 Ga and from 4.524 Ga until the present in different reservoirs defined by the age and the $\mathrm{Rb}-\mathrm{Sr}$ and $\mathrm{Sm}-\mathrm{Nd}$ isotopic systematics of the samples. Sources of isotopic data summarized in Borg and Drake (2005). Sources of REE data are Barrat et al., (2001, 2002), Dreibus et al. (2000; 2002), Jambon et al. (2002), Lodders (1998), Shira and Ebihara (2004), and Taylor et al., (2002).

Figure 5. Results of MELTS fractional crystallization modeling of Y980459 parent composition. Crystallization sequence and mineral compositions produced from a liquid that underwent fractional crystallization. The calculated crystallization sequence results in an assemblage that is is similar to the observed petrography of Y980459. Liquidus temperatures of Y980459 and QUE94201 determined experimentally by Dalton et al. (2005) and Mikouchi et al. (2001), respectively. The composition of pigeonite cores in QUE94201 from Kring et al. (2003), McKay et al. (1996), McSween et al. (1996), and Mikouchi et al. (1998) are a close match to those produced at $1170{ }^{\circ} \mathrm{C}$ by the MELTS algorithm.

Figure 6. $\mathrm{Mg} \#$ versus $\mathrm{SiO}_{2}, \mathrm{Al}_{2} \mathrm{O}_{3}, \mathrm{FeO}, \mathrm{MgO}, \mathrm{CaO}, \mathrm{Na}_{2} \mathrm{O}$ weight percent (wt. \%) of liquids calculated by MELTS assuming fractional crystallization at 1 bar pressure from Y98 (small solid 
symbols at $\mathrm{Mg} \#=67)$ at $\mathrm{fO}_{2}=\mathrm{QFM}-3$. Open symbols represent $10^{\circ} \mathrm{C}$ steps starting at the liquidus temperature of $1430^{\circ} \mathrm{C}$. The $1170^{\circ} \mathrm{C}$ liquid is produced by $43 \%$ fractional crystallization of olivine, orthopyroxene, pigeonite, and spinel in the proportions 38:40:19:2 and is a very good match to the composition of QUE94201 (large solid symbols at $\mathrm{Mg} \#=38$ where symbol size reflects range of published compositions; see Table 3). Thus, QUE94201 has major element abundances that are consistent with formation from a parental liquid with the characteristics of Y98 by fractional crystallization.

Figure 7. Pyroxene compositions calculated by MELTS from $1320-1170^{\circ} \mathrm{C}$ assuming fractional crystallization (open circles) under the conditions outlined in the Figure 6 caption. Gray field represents pyroxene compositions in Y98 from Mikouchi et al. (2004) and open field represents pyroxene compositions of QUE94201 from Kring et al. (2003), McKay et al. (1996), McSween et al. (1996), and Mikouchi et al. (1998). The compositions of the most magnesian Y98 pyroxenes are nearly identical to the $1320^{\circ} \mathrm{C}$ pyroxenes calculated by MELTS. Likewise the most magnesian pyroxene cores observed in QUE94201 are nearly identical to those calculated by MELTS at $1170^{\circ} \mathrm{C}$. The composition of pyroxene cores in NWA1195, DaG, SaU, and Dhofar 019 (solid triangles, data from Zipfel et al., 2000; Irving et al., 2002; Taylor et al., 2002) are also a close compositional match to pyroxenes calculated by MELTS between 1320 and $1170^{\circ} \mathrm{C}$. The pyroxene compositions in this suite of samples are thus consistent with fractional crystallization from a parental magma with the characteristics of Y98. Diamonds represent pyroxene compositions calculated by MELTS from $1160-1000^{\circ} \mathrm{C}$ assuming equilibrium crystallization. Similarities between these calculated pyroxene compositions and those observed 
in QUE94201 suggest that once fractional crystallization ceased, QUE94201 solidified in a closed system.

Figure 8. Results of the trace element model assuming fractional crystallization from a Y98-like parent. Triangles represent the Y98 whole-rock composition (Shirai and Ebihara, 2004) and squares represent the QUE94201 bulk rock analysis of Dreibus et al. (1996). The solid line is the QUE94201 whole rock composition of McSween et al. (1996). Circles represent a calculated composition that is constructed assuming Y98 is the parent and using mineral modes and extent of crystallization (i.e. $43 \%$ fractional crystallization) determined by MELTS for the $1170^{\circ} \mathrm{C}$ QUE94201-like liquid. Small diamonds represent 2 and 4\% addition of merrillite to the modeled melt composition. Addition of small amounts of merrillite raises the REE abundances of the modeled melt and suggests that differences between the modeled QUE94201 melt and various QUE94201 bulk rock analyses reflect variable proportions of merrillite in the analyzed samples. The similarity between the modeled and measured composition is consistent with formation of QUE94201 by fractional crystallization from a Y98-like parent.

Figure 9. Cartoon depicting potential petrogenetic relationships between the shergottites. The isotopic compositions of shergottite source regions reflect proportions of depleted mantle (dark gray) and enriched mantle (light gray with squiggled lines) components in the source region. On this diagram, samples are linked to individual volcanic centers by their crystallization ages and to specific source region types (i.e., depleted, enriched, etc.) by their incompatible element and isotopic systematics (see text). Major element variations reflect degree of fractional crystallization the parental magmas underwent in magma chambers prior to rising to the surface. 
Although the cartoon depicts two magma chambers for the 175 and 340 Ma samples, the geometry of the conduit system associated with the martian basalts is unconstrained. The two magma chambers are therefore drawn to depict two recharge events, in which different parental magmas are introduced into the volcanic plumbing system of an individual volcanic center. These recharge events may be temporally separated at the extent of the analytical uncertainty of the ages ( $>2 \mathrm{Ma})$ and consequently may or may not use the same volcanic plumbing systems. Within individual magma chambers the field with slashed lines represents least fractionated olivine-phyric parental magmas, the field with small ovoids represents moderately fractionated olivine-orthopyroxene parental magmas, and the solid field represents the most fractionated basaltic shergottites. Note that because the more enriched component is drawn closer to the surface, magmas derived from more shallow depths are more enriched in incompatible elements in this diagram. However the position of this component in not constrained on Mars by the geochemistry, so that the correlation between depth and source composition depicted on this diagram is an artifact of the cartoon construction. Vertical relief is not to scale. 


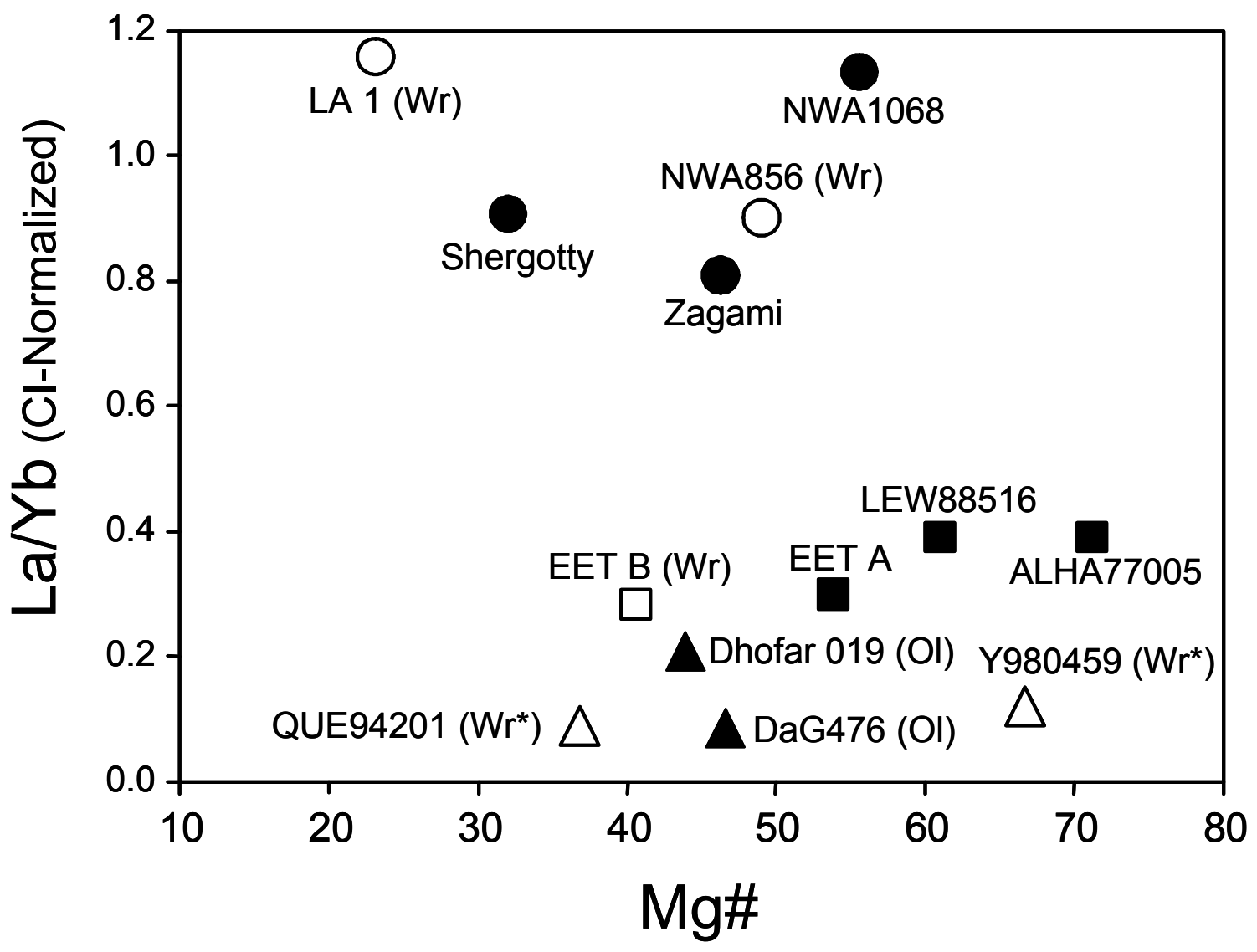

Figure 1 


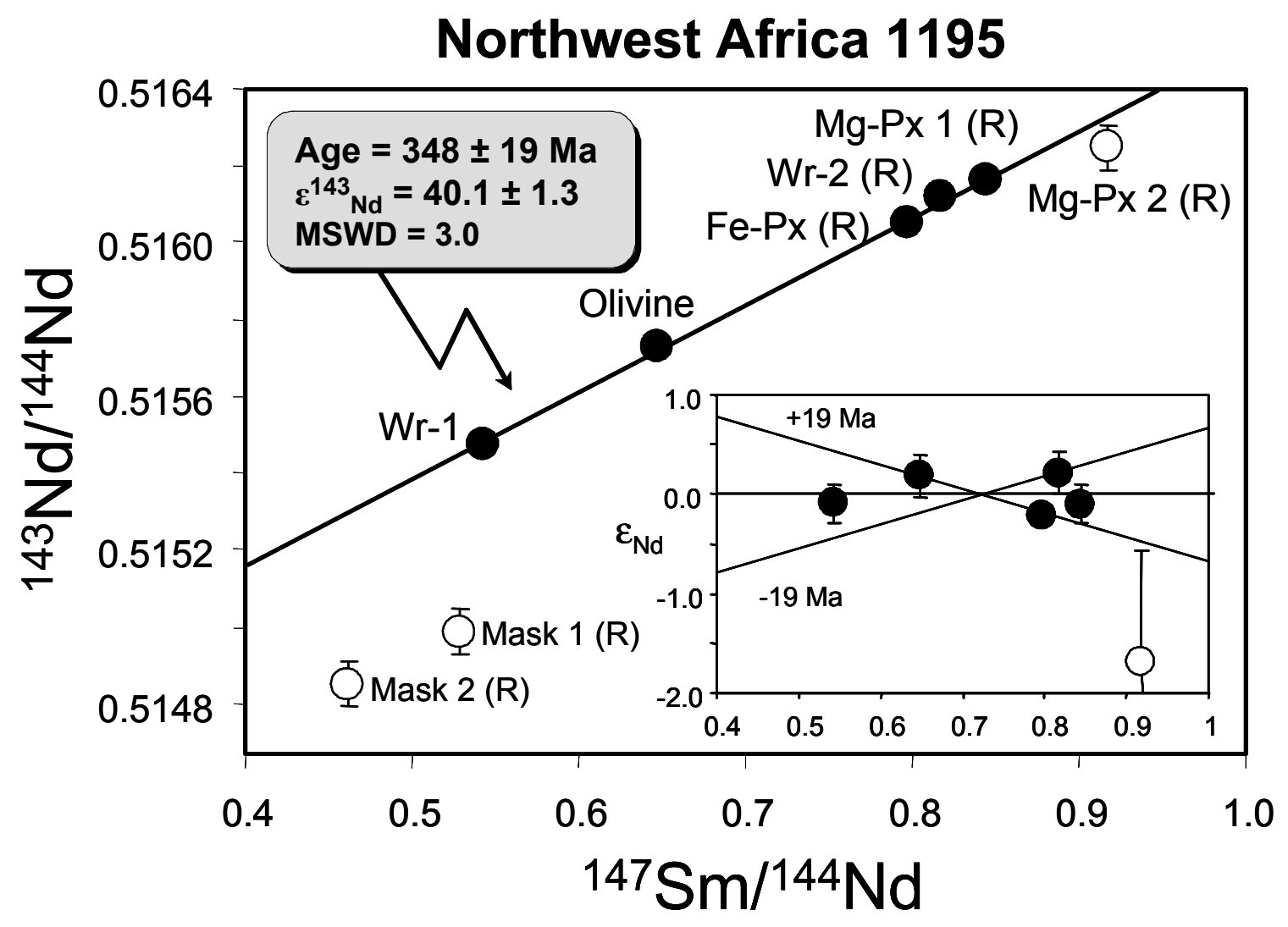

Figure 2 


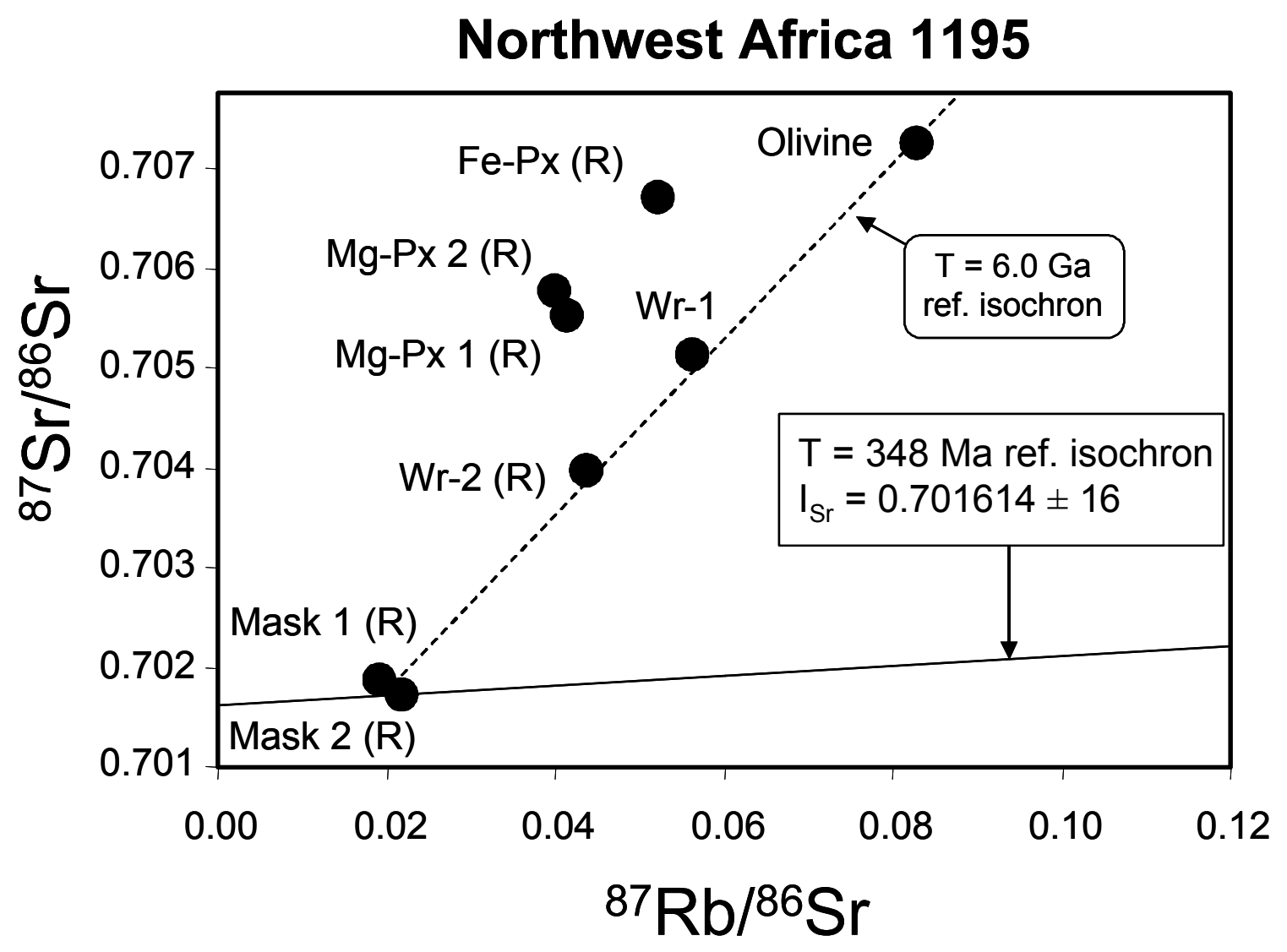

Figure 3 


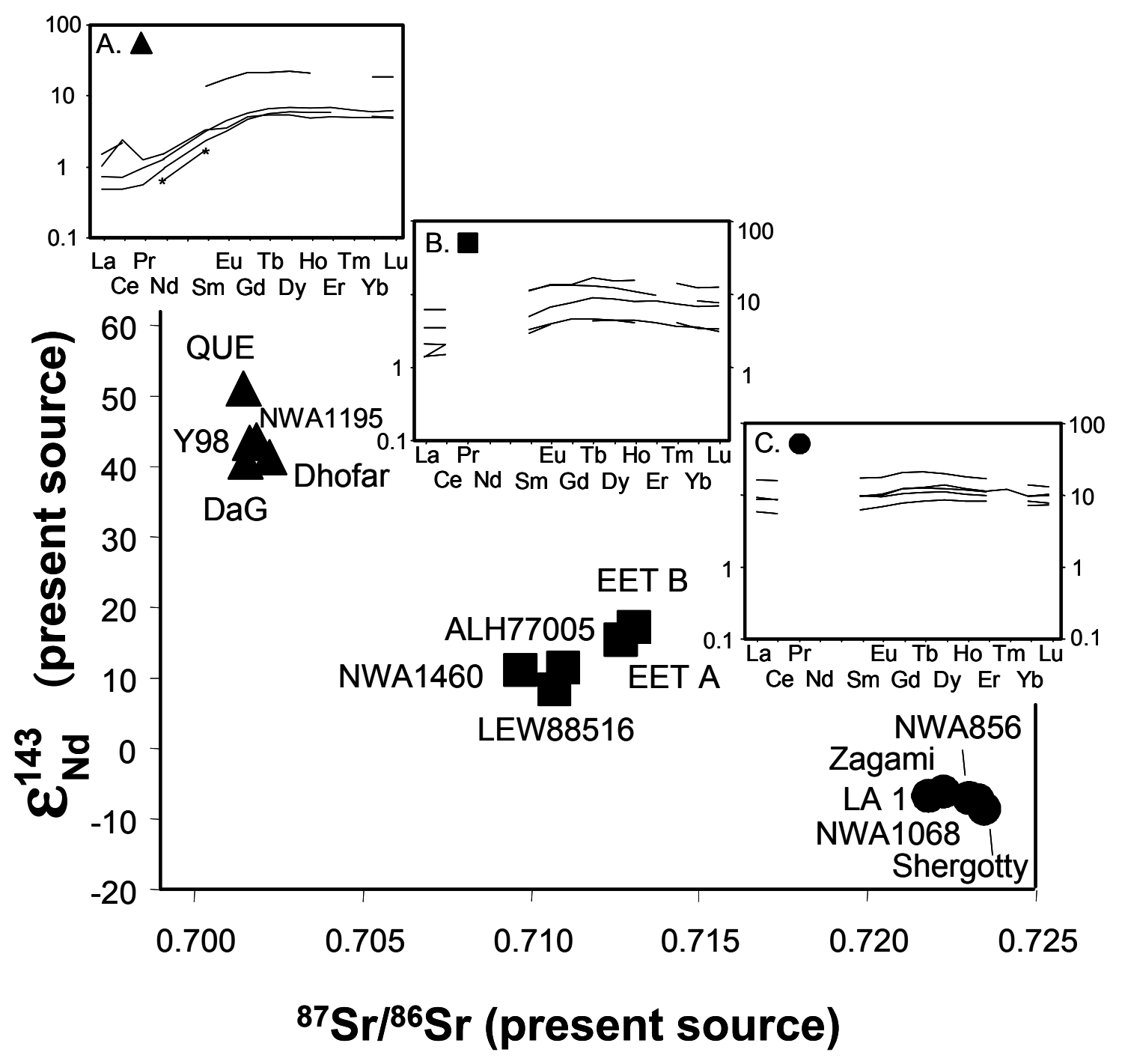

Figure 4 


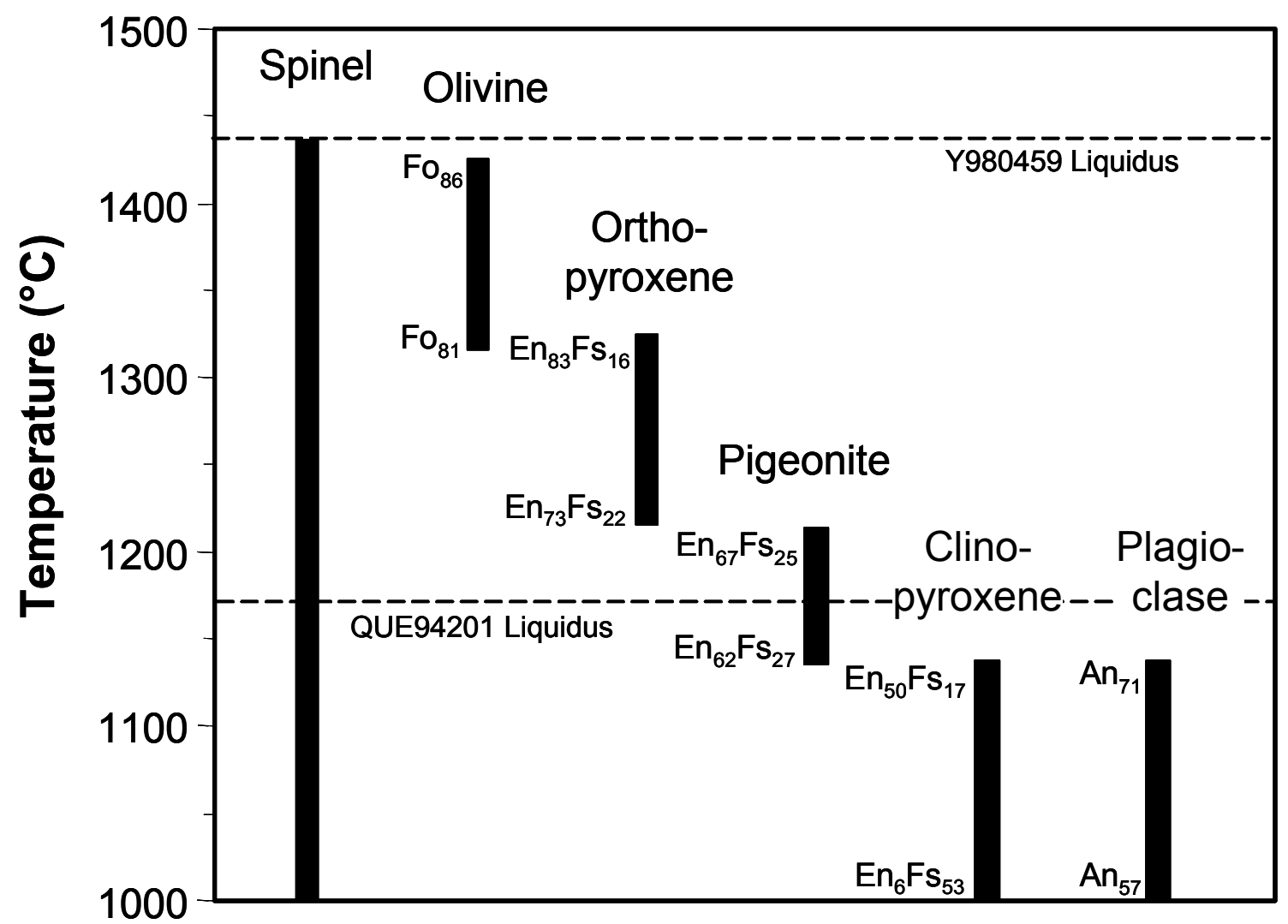

Figure 5 


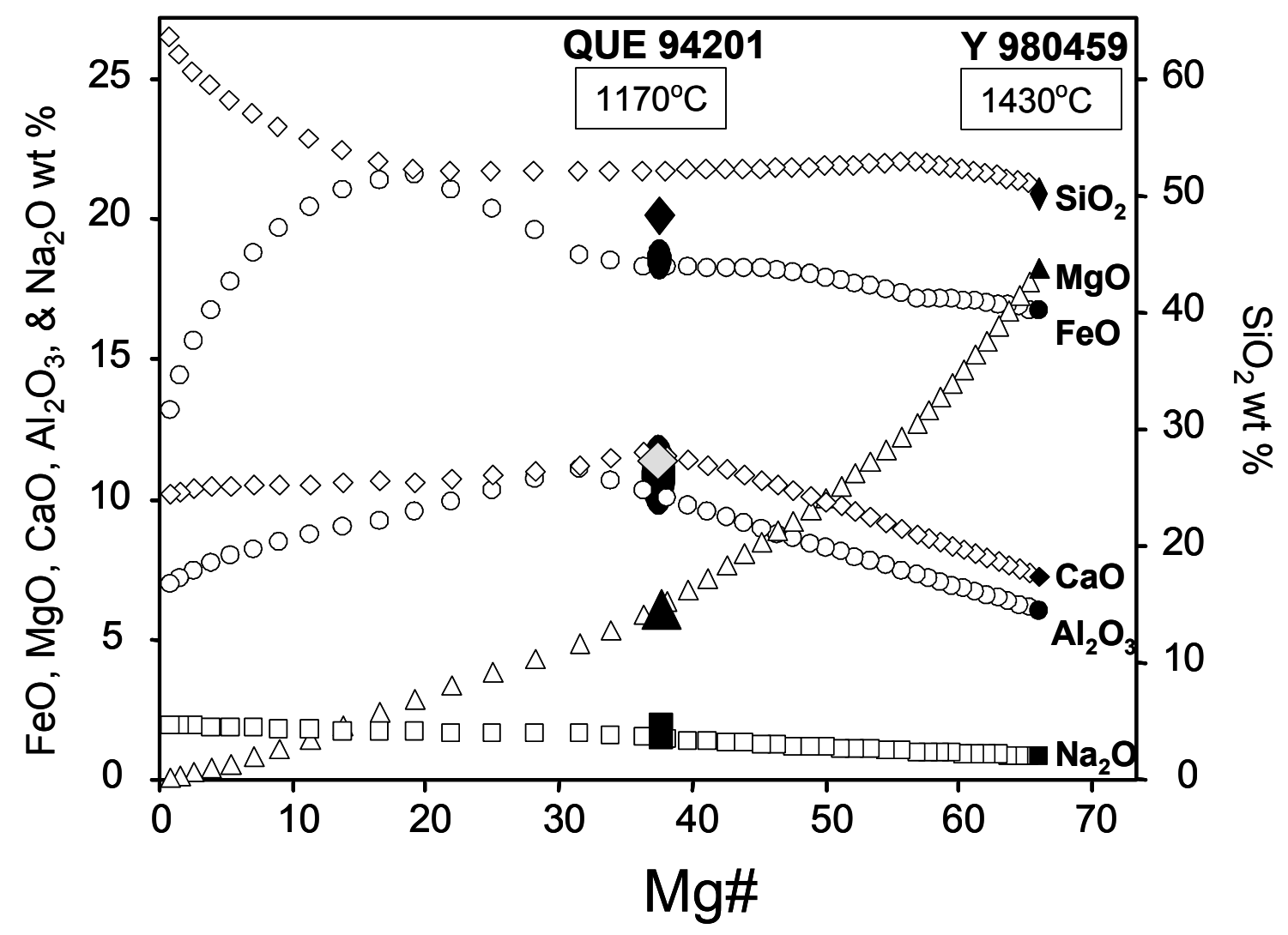

Figure 6 


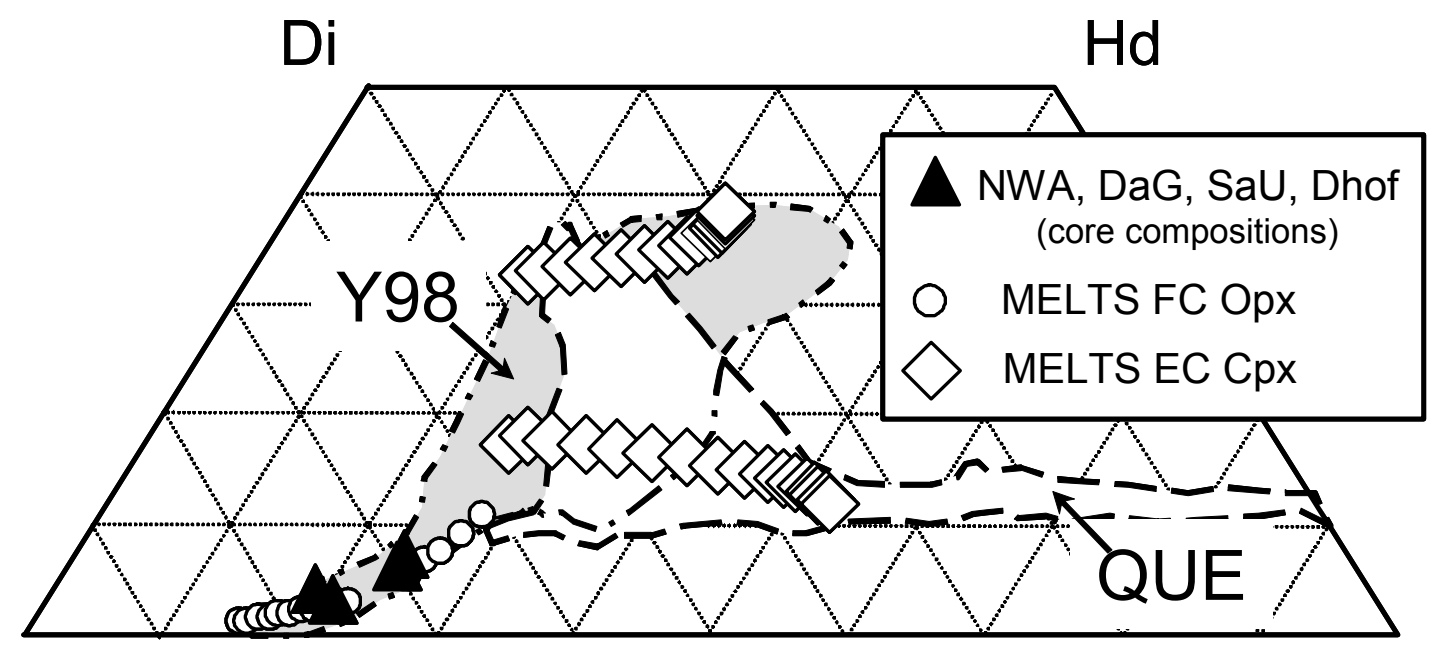

En

Fs

Figure 7 


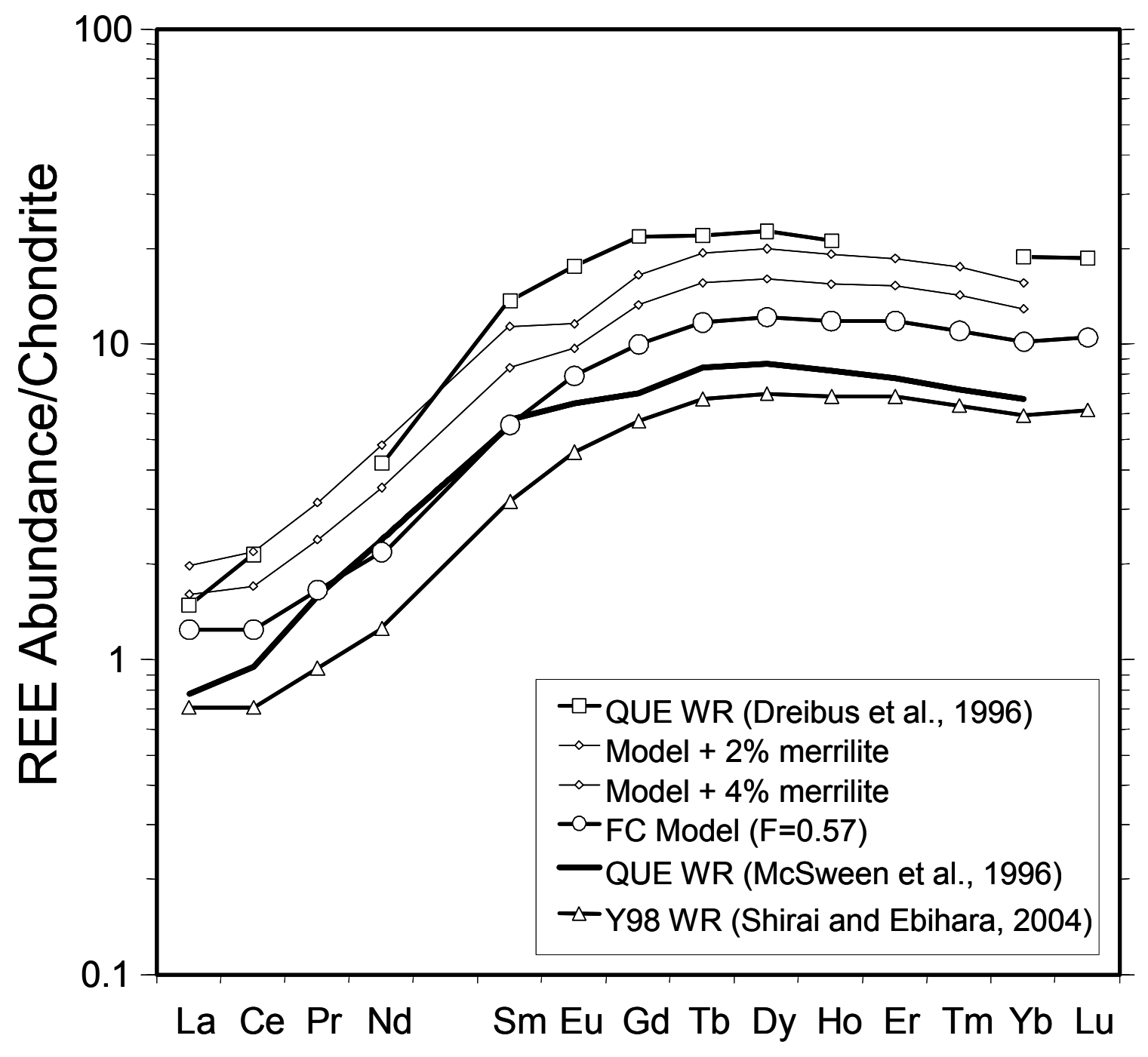

Figure 8 


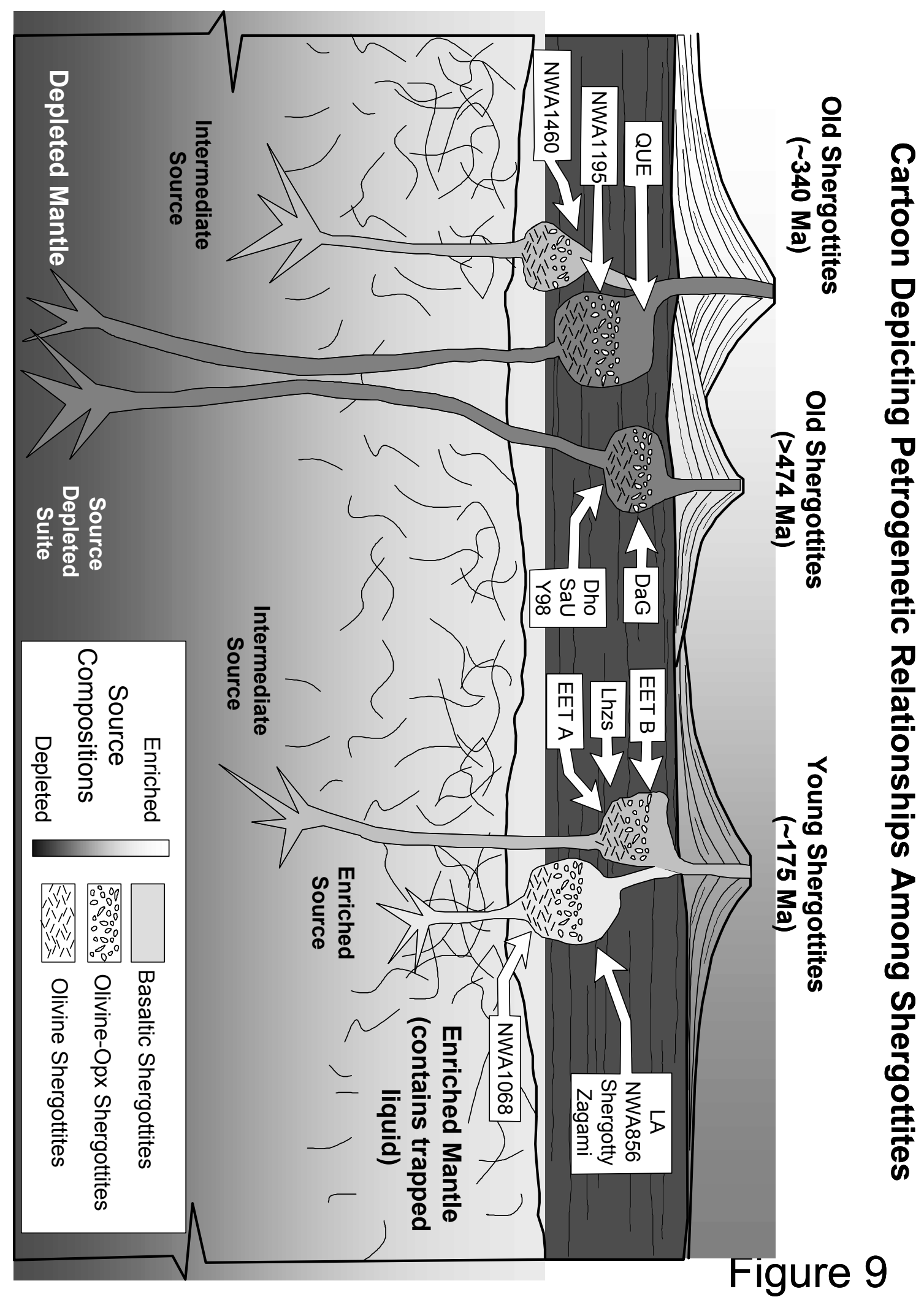

